Prepared in cooperation with the

U.S. Department of Agriculture

\title{
USDA
}

\section{A Regional Classification of the Effectiveness of Depressional Wetlands at Mitigating Nitrogen Transport to Surface Waters in the Northern Atlantic Coastal Plain}
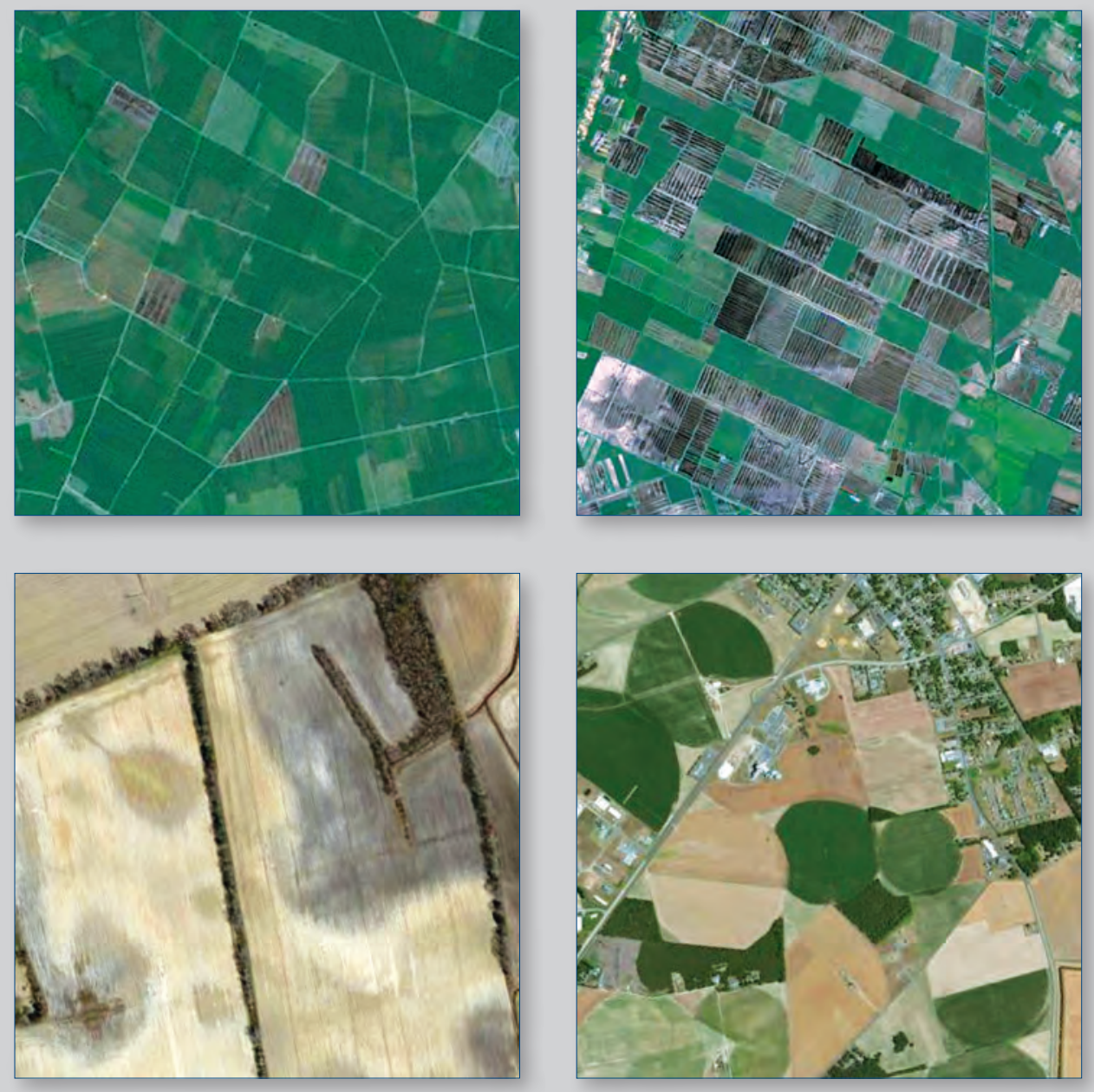

Scientific Investigations Report 2012-5266 
Cover. Clockwise from upper left: [1] Very Flat Poorly Drained Upland (VFPDU) in North Carolina, [2] Flat Poorly Drained Lowland (FPDL) in North Carolina, [3] circular fields in the Flat Sandy Uplands (FSU) near Hurlock, Maryland, and [4] Flat Sandy Lowland (FSL) in the northern part of the Delmarva Peninsula. Aerial photographs from the U.S. Department of Agriculture (USDA) National Agricultural Imagery Program (NAIP), 2007. 


\section{A Regional Classification of the Effectiveness of Depressional Wetlands at Mitigating Nitrogen Transport to Surface Waters in the Northern Atlantic Coastal Plain}

By Scott W. Ator, Judith M. Denver, Andrew E. LaMotte, and Andrew J. Sekellick

Prepared in cooperation with the

U.S. Department of Agriculture

Scientific Investigations Report 2012-5266 


\section{U.S. Department of the Interior \\ KEN SALAZAR, Secretary \\ U.S. Geological Survey \\ Marcia K. McNutt, Director}

U.S. Geological Survey, Reston, Virginia: 2013

For more information on the USGS - the Federal source for science about the Earth, its natural and living resources, natural hazards, and the environment, visit http://www.usgs.gov or call 1-888-ASK-USGS.

For an overview of USGS information products, including maps, imagery, and publications, visit http://www.usgs.gov/pubprod

To order this and other USGS information products, visit http://store.usgs.gov

Any use of trade, firm, or product names is for descriptive purposes only and does not imply endorsement by the U.S. Government.

Although this information product, for the most part, is in the public domain, it also may contain copyrighted materials as noted in the text. Permission to reproduce copyrighted items must be secured from the copyright owner.

Suggested citation:

Ator, S.W., Denver, J.M., LaMotte, A.E., and Sekellick, A.J., 2013, A regional classification of the effectiveness of depressional wetlands at mitigating nitrogen transport to surface waters in the Northern Atlantic Coastal Plain: U.S. Geological Survey Scientific Investigations Report 2012-5266, 23 p. 


\section{Contents}

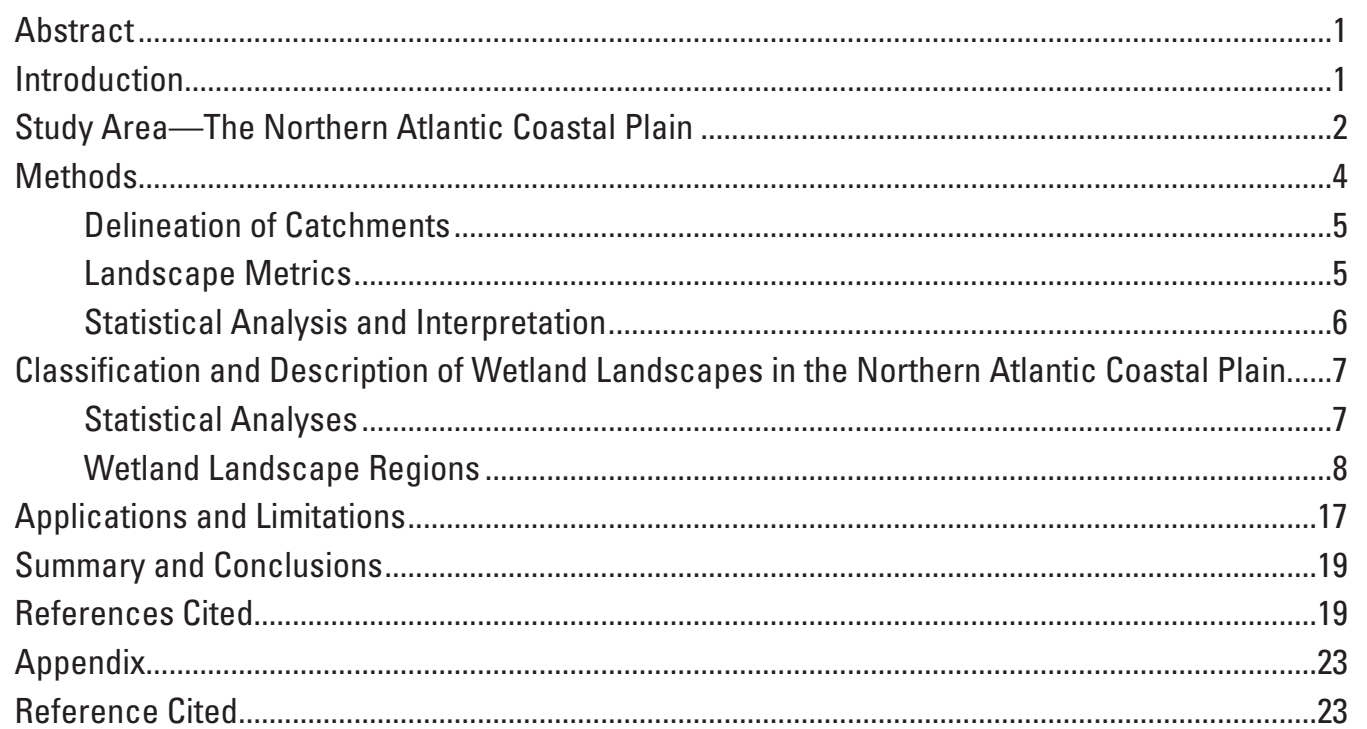




\section{Figures}

1. Map showing the distribution of palustrine wetlands within the Northern Atlantic Coastal Plain study area

2. Map showing elevation data from 2007 showing topographic depressions that are common in parts of the Northern Atlantic Coastal Plain, particularly in parts of the Delmarva Peninsula and North Carolina ...

3. Map showing fundamental landscape units defined by NHDPlus and 12-digit hydrologic units in part of the Northern Atlantic Coastal Plain

4. Boxplots showing distribution of selected topographic metrics computed from 30-meter elevation data among wetland landscape regions

5. Boxplots showing distribution of selected soil metrics among wetland landscape regions

6. Boxplots showing distribution of selected land cover among wetland landscape regions

7. Map showing wetland landscape regions within the Northern Atlantic Coastal Plain.

8. Aerial photograph showing parts of the Very Flat Poorly Drained Upland (VFPDU) in North Carolina

9. Aerial photograph showing that Flat Poorly Drained Lowlands (FPDL), as in this area of North Carolina, commonly form in large depressions such as Carolina Bays, and are often artificially drained for cultivation

10. Aerial photograph showing that in the Flat Sandy Lowlands (FSL) in the northern part of the Delmarva Peninsula $(A)$, wetlands often occur in isolated depressions, indicated by yellow arrows (such as Delmarva Bays), and minimal artificial drainage is required to support agriculture. Further south on the peninsula, however, $(B)$, natural drainage is extremely poor and extensive ditching is common

11. Aerial photograph showing that circular fields in the Flat Sandy Uplands (FSU) near Hurlock, Maryland are indicative of center-pivot irrigation systems. Because FSU watersheds are generally well-drained, irrigation rather than artificial drainage is often used to support crop production.

\section{Tables}

1. Results of principal components analysis on $\mathbf{1 6}$ landscape metrics defined for 33,799 individual catchments in the Northern Atlantic Coastal Plain 6

2. Summary of depressional wetland landscape regions within the Northern Atlantic Coastal Plain 


\section{Conversion Factors and Datums}

\begin{tabular}{lcl}
\hline \multicolumn{1}{c}{ Multiply } & By & To obtain \\
\hline & Length & \\
\hline centimeter $(\mathrm{cm})$ & 0.0328 & foot $(\mathrm{ft})$ \\
meter $(\mathrm{m})$ & 3.281 & foot $(\mathrm{ft})$ \\
kilometer $(\mathrm{km})$ & 0.6214 & mile $(\mathrm{mi})$ \\
\hline \multicolumn{2}{c}{ Area } & \\
\hline square kilometer $\left(\mathrm{km}^{2}\right)$ & 247.1 & acre \\
square kilometer $\left(\mathrm{km}^{2}\right)$ & 0.3861 & square mile $\left(\mathrm{mi}^{2}\right)$ \\
\hline
\end{tabular}

Temperature in degrees Fahrenheit $\left({ }^{\circ} \mathrm{F}\right)$ may be converted to degrees Celsius $\left({ }^{\circ} \mathrm{C}\right)$ as follows:

$$
{ }^{\circ} \mathrm{C}=\left({ }^{\circ} \mathrm{F}-32\right) / 1.8
$$

Vertical coordinate information is referenced to the North American Vertical Datum of 1988 (NAVD 88).

Horizontal coordinate information is referenced to the North American Datum of 1983 (NAD 83).

Altitude, as used in this report, refers to distance above the vertical datum. 



\title{
A Regional Classification of the Effectiveness of Depressional Wetlands at Mitigating Nitrogen Transport to Surface Waters in the Northern Atlantic Coastal Plain
}

\author{
By Scott W. Ator, Judith M. Denver, Andrew E. LaMotte, and Andrew J. Sekellick
}

\begin{abstract}
Nitrogen from nonpoint sources contributes to eutrophication, hypoxia, and related ecological degradation in Atlantic Coastal Plain streams and adjacent coastal estuaries such as Chesapeake Bay and Pamlico Sound. Although denitrification in depressional (non-riparian) wetlands common to the Coastal Plain can be a significant landscape sink for nitrogen, the effectiveness of individual wetlands at removing nitrogen varies substantially due to varying hydrogeologic, geochemical, and other landscape conditions, which are often poorly or inconsistently mapped over large areas. A geographic model describing the spatial variability in the likely effectiveness of depressional wetlands in watershed uplands at mitigating nitrogen transport from nonpoint sources to surface waters was constructed for the Northern Atlantic Coastal Plain (NACP), from North Carolina through New Jersey.

Geographic and statistical techniques were used to develop the model. Available medium-resolution $(1: 100,000-$ scale) stream hydrography was used to define 33,799 individual watershed catchments in the study area. Sixteen landscape metrics relevant to the occurrence of depressional wetlands and their effectiveness as nitrogen sinks were defined for each catchment, based primarily on available topographic and soils data. Cluster analysis was used to aggregate the 33,799 catchments into eight wetland landscape regions (WLRs) based on the value of three principal components computed for the 16 original landscape metrics. Significant differences in topography, soil, and land cover among the eight WLRs demonstrate the effectiveness of the clustering technique. Results were used to interpret the relative likelihood of depressional wetlands in each WLR and their likely effectiveness at mitigating nitrogen transport from upland source areas to surface waters.

The potential effectiveness of depressional wetlands at mitigating nitrogen transport varies substantially over
\end{abstract}

different parts of the NACP. Depressional wetlands are common in three WLRs covering 32 percent of the area, and have a relatively high potential to mitigate nitrogen transport from nonpoint sources. Conversely, 37 percent of the study area includes rolling hills with relatively high slope and relief, and little likelihood of depressional wetlands. The remainder of the Coastal Plain includes relatively flat watersheds with moderate to low relative likelihood of nitrogen mitigation. The delineation of WLRs in this model should be useful for targeting wetland conservation or restoration efforts, and for estimating the effects of depressional wetlands on the regional nitrogen budget, but should be considered in light of limitations and assumptions inherent in the model.

\section{Introduction}

Excessive nitrogen from nonpoint sources has contributed to eutrophic and hypoxic conditions and related ecological degradation of surface waters worldwide (Howarth and others, 1996; Vitousek and others, 1997; Carpenter and others, 1998). Rivers of the eastern United States export 3 to 14 times more nitrogen (commonly in the form of nitrate) than under natural conditions, and average nitrogen yields from the northeastern United States to the North Atlantic Ocean are the greatest in the Western Hemisphere (Howarth and others, 1996). Nonpoint sources of nitrogen include numerous human activities, but are often dominated by agricultural fertilizer applications (Howarth and others, 1996; Dubrovsky and others, 2010; Ator and others, 2011). Whereas point sources contribute the majority of nitrogen to certain individual streams, they account for less than 20 percent of the total nitrogen delivered to Chesapeake Bay (Ator and others, 2011) or to the wider North Atlantic Ocean (Howarth and others, 1996). Nitrate carried in 
groundwater discharging to streams is a substantial nonpoint source of nitrogen in surface water (Dubrovsky and others, 2010). In the Northern Atlantic Coastal Plain (NACP) adjacent to Mid-Atlantic coastal estuaries, groundwater provides 40 to 95 percent of streamflow (Sinnott and Cushing, 1978; Leahy and Martin, 1993) and as much as 70 percent of the nitrogen flux (in the form of nitrate) in streams (Domagalski and others, 2008; Ator and Denver, 2012). Although primary production in streams and some tidal waters is typically limited by phosphorus concentrations, production and resulting eutrophication in temperate estuaries is often nitrogen-limited (Vitousek and others, 1997; Prasad and others, 2010).

Wetlands mitigate nitrate transport from nonpoint sources to surface waters in many landscapes and are often a key component of management and restoration strategies to reduce nitrogen pollution (Brinson and Eckles, 2011). Wetlands are commonly interspersed with agricultural land in Coastal Plain settings where they occur in riparian zones, depressions, and on flats (De Steven and Lowrance, 2011). Organic matter and reducing conditions typical of wetlands promote the removal of nitrogen as dissolved nitrate to the atmosphere through denitrification (Howarth and others, 1996; Whigham and Jordan, 2003). This process occurs where water containing nitrate passes through any sufficiently reducing environment (Puckett, 2004), and has been observed in riparian and hyporheic sediments (De Steven and Lorwrance, 2011; Kennedy and others, 2009; Hill, 1996; Puckett and others, 2008) and along groundwater flowpaths (Tesoriero and others, 2000; Böhlke and others, 2007; Mehnert and others, 2007; Denver and others, 2010). The effects of depressional wetlands on nitrate reduction have been less widely studied (Leibowitz and Nadeau, 2003). Whereas the restoration of riparian zones is the most widespread wetland conservation practice, the restoration of depressional wetlands is also a common practice in the Coastal Plain (DeSteven and Lowrance, 2011). The restoration of cultivated former depressional wetlands where soils may retain organic matter and reducing conditions are sufficient to promote denitrification is most likely to be successful (David and others, 2009; De Steven and Lowrance, 2011). Such restorations often include restoring wetland hydrology through the blocking of ditches installed to promote cultivation and allowing the re-establishment of wetland vegetation (De Steven and others, 2006).

Coupled conceptual and geographic models can be useful for understanding and predicting the spatial variability in the effectiveness of wetlands at reducing nitrogen transport. A thorough understanding of nitrogen mitigation and other services provided by wetlands or other ecosystem compartments is critical in assessing their effects on regional water quality and for prioritizing management or restoration investment (Palmer and Filoso, 2009). Nitrogen losses in wetlands vary spatially and temporally in response to similar variability in hydrology and geochemistry, however, and extrapolating observations of nitrogen losses in local wetlands to large regions is therefore difficult (Howarth and others, 1996). Predicting nitrogen fate and transport can be particularly complicated where groundwater delivers nitrate to streams at depth beneath reducing environments associated with wetlands (Böhlke and Denver, 1995; Hill, 1996; Gold and others, 2001; Puckett, 2004). Winter (2001) proposed the concept of hydrologic landscapes composed of various combinations of uplands, lowlands, and intervening slopes as an objective framework for predicting physical hydrology and resulting geochemical and biological processes in different areas. Geographic models delineating selected relevant landscape features over large areas coupled with conceptual models of hydrology and nitrate transport through individual watersheds, for example, can be useful for understanding and (or) predicting the spatial variability in the effectiveness of wetlands at mitigating nitrogen transport from nonpoint sources to surface waters.

A regional geographic model predicting the mitigation of nitrogen transport from nonpoint sources to surface waters by depressional (non-riparian) wetlands located in watershed uplands is presented and discussed in this report. The model was developed for the NACP (New Jersey through North Carolina) (fig. 1), where depressional wetlands, including Carolina Bays and smaller Delmarva Bays, are common. Multivariate statistical techniques, such as principal components analysis (PCA) and cluster analysis, have been frequently used to classify landscapes on the basis of physical hydrology or watershed characteristics (for example, Mosely, 1981; Lipscomb, 1998; Preston, 2000; Chiang and others, 2002; Caratti and others, 2004; Wolock and others, 2004; Rao and Srinivas, 2006; Isik and Singh, 2008). In this study, however, such techniques were used with available geographic data particularly relevant to nitrogen fate and transport around depressional wetlands to classify 33,799 individual watershed catchments in the NACP into wetland landscape regions (WLRs) (see Appendix). The predicted likelihood of depressional wetlands to occur and to mitigate the transport of nonpoint-source nitrogen to surface waters in each WLR is described. Implications for regional watershed management and restoration also are discussed.

\section{Study Area-The Northern Atlantic Coastal Plain}

The NACP study area covers approximately 114,000 square kilometers $\left(\mathrm{km}^{2}\right)$ in the eastern United States and includes areas of the Atlantic Coastal Plain Physiographic Province (Fenneman and Johnson, 1946) in five states (North Carolina, Virginia, Maryland, Delaware, and New Jersey) and the District of Columbia (fig. 1). The NACP is underlain by unconsolidated and (in parts of North Carolina) semi-consolidated sediments that thicken from 0 meters $(\mathrm{m})$ in the west at the Fall Line to more than 3,000 $\mathrm{m}$ along the North Carolina coast (Winner and Coble, 1996; Ator and others, 2005). The texture of near-surface sediments varies laterally and vertically from relatively impermeable silt and clay to extremely 


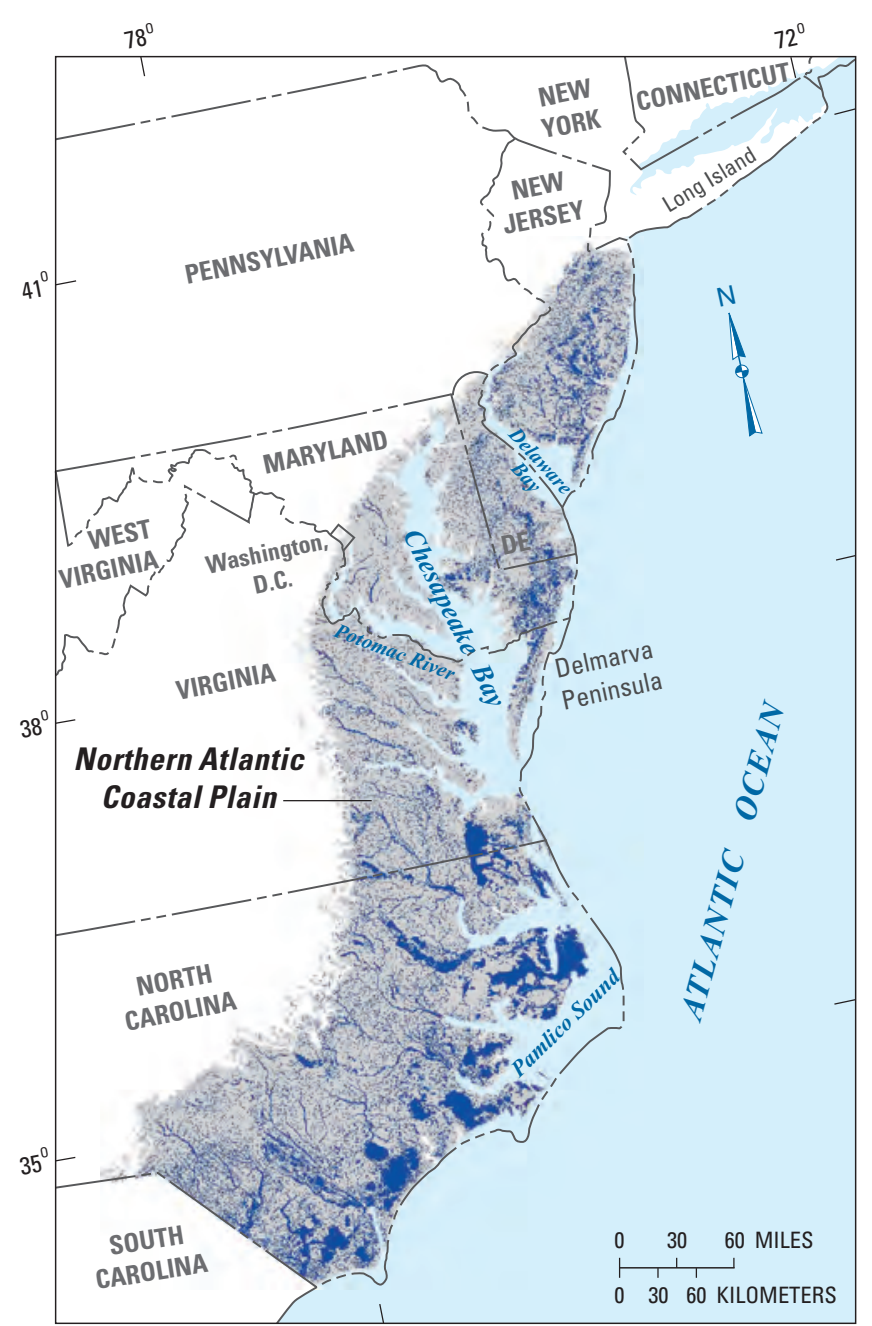

Base from U.S. Geological Survey,1:2,000,000 DLG,

Albers Equal-Area Conic Projection, NAD 1983

\section{EXPLANATION}

Palustrine wetlands (National Wetlands Inventory, U.S. Fish and Wildlife Service, 2011)

Northern Atlantic Coastal Plain

Figure 1. The distribution of palustrine wetlands within the Northern Atlantic Coastal Plain study area.

permeable sand and gravel. Soils are generally permeable, but can be quite variable in texture reflecting the variability in geologic parent material. Much of the NACP is relatively flat and low-lying (particularly along the coast of the Atlantic Ocean and major estuaries), although stream incision and land-surface slopes generally increase toward the west.

Climate in the NACP is humid and temperate to subtropical. Precipitation averages approximately 120 centimeters per year, about half (51 percent) of which returns to the atmosphere through evaporation or transpiration (Leahy and Martin, 1993). Approximately two-thirds of the remaining precipitation recharges the shallow groundwater (Leahy and Martin, 1993). Because of the humid climate and commonly flat, low-lying topography in the NACP, the water table generally occurs within a few meters of the land surface. Groundwater provides 40 to 95 percent of flow in Coastal Plain streams (Sinott and Cushing, 1978; Leahy and Martin, 1993); most water moves through the surficial aquifer system from the water table to discharge areas in local streams within a few decades (Dunkle and others, 1993; Böhlke and Denver, 1995; McFarland, 1995; Speiran, 1996; Szabo and others, 1996; Kauffman and others, 2001).

Abundant nonpoint nitrogen sources and commonly permeable soils and near-surface sediments in the NACP contribute to widespread nitrate contamination in shallow groundwater and surface waters. Although the NACP is predominantly forested, areas of intensive agriculture (particularly on the Delmarva Peninsula and in parts of North Carolina) and densely populated urban areas (particularly along the Fall Line north of the Washington, D.C. area) are common. Nitrate attributable to human sources has been reported in the aquifer since at least the early 1970s, and concentrations exceeding the Federal drinking-water standard of 10 milligrams per liter $(\mathrm{mg} / \mathrm{L})$ are not uncommon (Cushing and others, 1973; Bachman, 1984; Denver, 1989; Böhlke and Denver, 1995; Eckhardt and Stackelberg, 1995; Bolton, 1996; Spruill and others, 1997; Debrewer and others, 2008; Ator, 2008; Denver and others, 2010). As the predominant source of water to NACP streams, groundwater also contributes as much as 70 percent to the total nitrogen load in many NACP streams (Bachman and Phillips, 1996; Ator, Denver, and Brayton, 2005; Domagalski and others, 2008; Ator and Denver, 2012) and downstream coastal estuaries. This substantial export of nitrogen is associated with documented waterquality problems. For example, only 12 percent of Chesapeake Bay, the largest estuary in North America, met ecological criteria for dissolved oxygen in 2007 (U.S. Environmental Protection Agency, 2008), and a Total Maximum Daily Load was established for nitrogen in the bay watershed in 2010 (U.S. Environmental Protection Agency, 2011). Other MidAtlantic estuaries in which nitrogen has contributed to poor water quality include Delaware Bay, Delaware and Maryland Coastal Bays, Barnegat Bay, and Albemarle, Long Island, and Pamlico Sounds (Spruill and others, 2005; U.S. Environmental Protection Agency, 2007).

The NACP has one of the most wetland-rich landscapes in the United States (Carter, 1996) (fig. 1). Depressional (non-riparian) wetlands, including Carolina Bays and smaller Delmarva Bays, are abundant and represent a significant potential landscape sink for nitrate from agricultural and other sources. They are found in various landscape positions from relatively flat interstream divides, isolated topographically low depressions in otherwise well-drained landscapes, to coastal terraces where they are commonly embedded in areas with large expanses of wetland flats (Tiner, 1996; De Steven and Lowrance, 2011) (fig. 2). Pocosins, palustrine wetlands with evergreen scrub vegetation, are common in the 


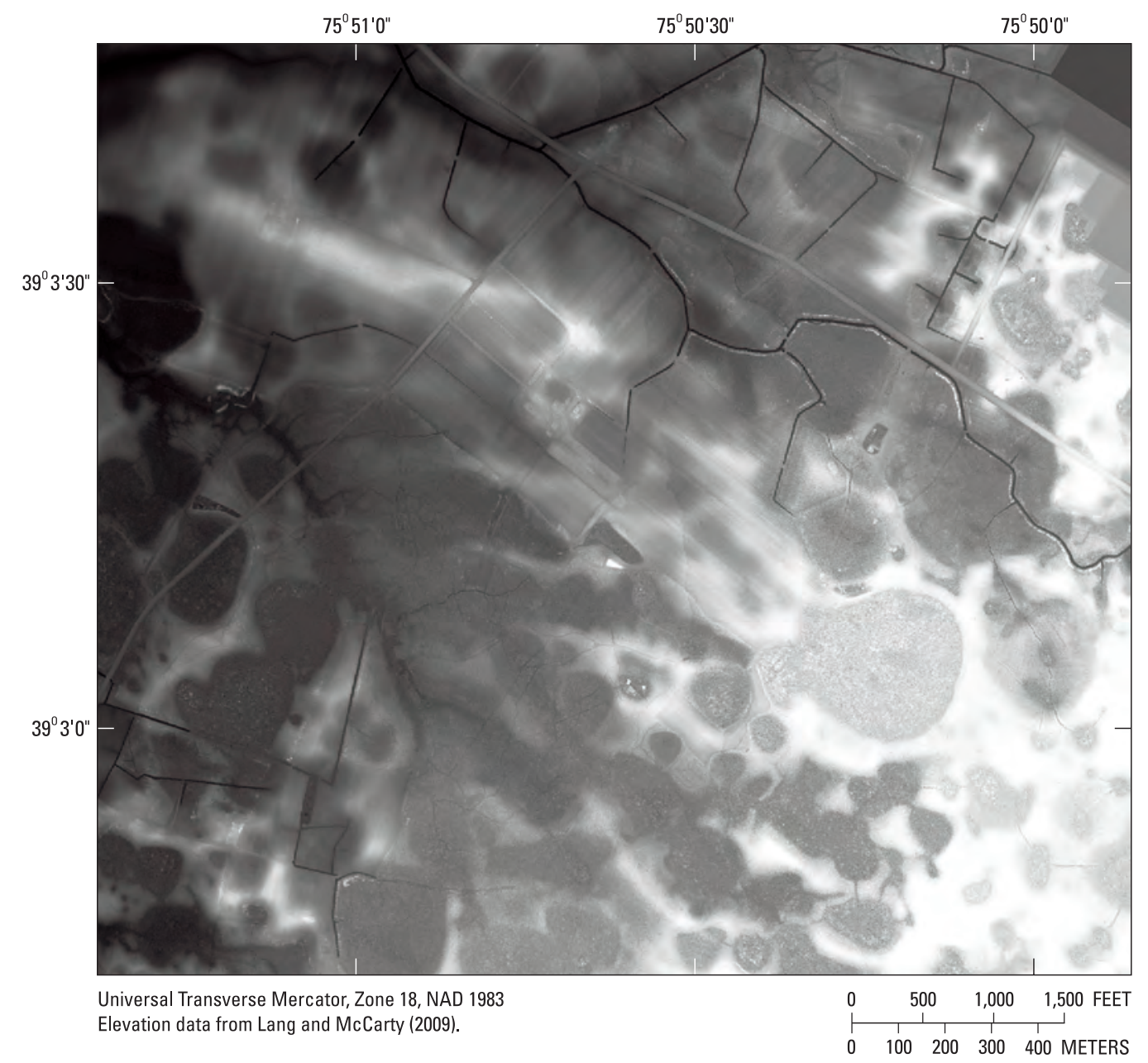

Figure 2. Elevation data from 2007 showing topographic depressions that are common in parts of the Northern Atlantic Coastal Plain, particularly in parts of the Delmarva Peninsula and North Carolina. Lighter colors indicate higher elevations.

southern part of the NACP (Richardson, 1983; Tiner, 1996). Nitrate in groundwater in poorly drained areas of the NACP that promote the formation of wetlands generally occurs at lower concentrations than in well-drained areas (Ator, 2008). Many of the areas with agricultural land use and lower nitrate concentrations were previously wetlands that have been drained, such as in coastal North Carolina, where 50 percent of previous wetland areas have been converted mostly for agricultural use (Dahl, 1990). Whether wetlands or other landscape sinks will intercept and reduce nitrate in groundwater from agricultural sources depends on local hydrogeologic conditions including the orientation of groundwater flowpaths, the location of the wetlands within the groundwater-flow system, and the thickness of the surficial aquifer (Böhlke and Denver, 1995; Leibowitz and Nadeau, 2003; Whigham and Jordan, 2003; Puckett, 2004). These factors vary regionally and control how much nitrate encounters reducing conditions conducive to denitrification.

\section{Methods}

Geographic and statistical techniques were used to create a geographic model that identifies and delineates WLRs, areas of the NACP within which depressional wetlands have a similar potential to mitigate nitrogen transport from agricultural sources to local streams. Methods for defining WLRs were adapted from those used by Wolock and others (2004) to define hydrologic landscapes for the United States. Fundamental landscape units for the model were defined by individual watershed catchments within the study area. Relevant landscape (geographic) metrics were compiled or computed for each catchment and multivariate statistical techniques (PCA and cluster analyses) were used to classify catchments into groups (WLRs) with similar values for those metrics. Conceptual models were developed to predict likely effects of depressional wetlands on regional nitrogen transport in each WLR. 


\section{Delineation of Catchments}

Individual watershed catchments within the NACP study area for use as fundamental landscape units were developed from the geospatial dataset NHDPlus, a medium resolution (1:100,000-scale) representation of stream hydrography built upon the National Hydrography Dataset (NHD) (Johnston and others, 2009; Horizon Systems, 2010; Simley and Carswell, 2010). The model area was defined as areas of 12-digit hydrologic units (HUC12s; Natural Resources Conservation Service, 2007a; U.S. Geological Survey and U.S Department of Agriculture, National Resources Conservation Service, 2012) that intersect the NACP. The model area thus extends beyond the Coastal Plain, but was selected to support summarization and reporting of results for $\mathrm{HUC12s}$ (which are generally familiar to watershed managers) and to provide flexibility in the computation of landscape metrics based on watersheds at multiple scales (fig. 3). Catchments contributing to individual stream reaches as defined by NHDPlus in this area constitute the fundamental landscape units for modeling, and define the finest spatial resolution of model predictions. Catchments smaller than $0.5 \mathrm{~km}^{2}$ or including more than 50 percent open water (LaMotte, 2008a, 2008b) were omitted. Catchments with more than 75 percent of land area below $2 \mathrm{~m}$ in elevation (Gesch and others, 2009) also were omitted to avoid the influence of tidal conditions. Catchments with missing soils data (Natural Resources Conservation Service, 2007b) were similarly dropped from consideration in the model; these areas generally occur in heavily developed urban areas that probably lack natural soils. The remaining 33,799 individual catchments within the model area have a median incremental area of 2.2 $\mathrm{km}^{2}$ (interquartile range, $2.6 \mathrm{~km}^{2}$ ).

\section{Landscape Metrics}

Landscape metrics (geographic variables) for inclusion in the model were derived mainly from soils data and topographic metrics to represent conditions in each catchment that are particularly relevant to nitrogen fate and transport around wetlands (table 1). Water is the primary vector for the transport of nitrogen in the NACP, much of which occurs through shallow groundwater in the form of dissolved nitrate (Böhlke and Denver, 1995; Bachman and Phillips, 1996; Ator and Denver, 2012). Understanding (and predicting) nitrogen fate and transport in the NACP therefore requires consideration of local hydrology and the occurrence of reducing conditions associated with wetlands that may promote nitrogen losses through denitrification.

Landscape metrics were selected primarily to represent the likelihood of depressional wetlands being present in model catchments and describe their position relative to local hydrologic flowpaths. The likelihood of wetlands being present is represented by topographic variables indicative of the flatness of the landscape and by soil variables representative of soil texture and drainage (table 1). Topographic metrics were

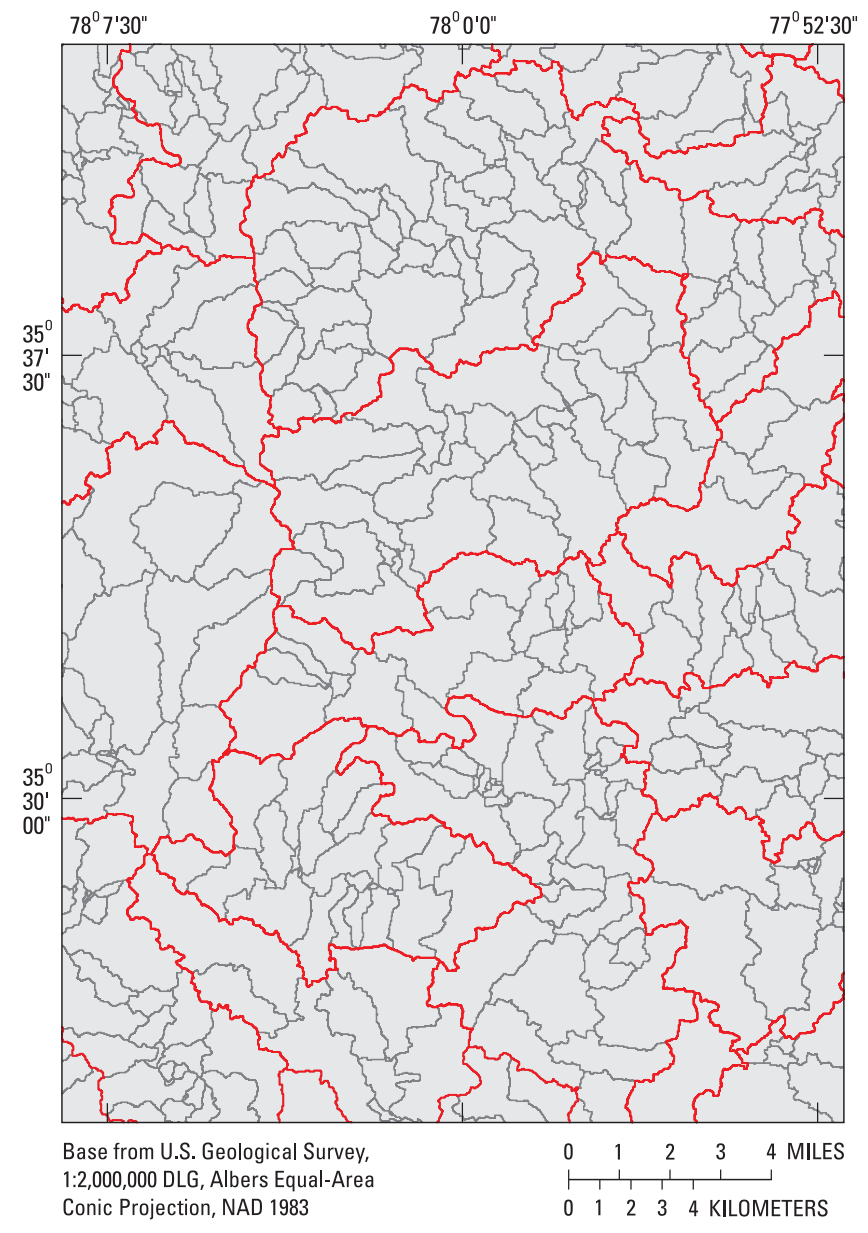

\section{EXPLANATION}

12-digit hydrologic units (Natural Resources Conservation Service, 2007a; U.S. Geological Survey and U.S. Department of Agriculture, National Resources Conservation Service, 2012)

Fundamental landscape units

Figure 3. Fundamental landscape units defined by NHDPlus and 12-digit hydrologic units in part of the Northern Atlantic Coastal Plain.

computed from 30-m digital elevation data (Gesch and others, 2009); soil metrics were computed from the Soil Survey Geographic Database (SSURGO) data in conformance with National Resources Conservation Service (NRCS) methods for aggregation for area-depth weighted averaging (Natural Resources Conservation Service, 2007b). Topographic wetness index (TWI), a function of slope and upstream contributing area (Beven and Kirk, 1979; Wolock and McCabe, 1995) was computed from NHDPlus attributes (U.S. Environmental Protection Agency, 2007; Horizon Systems, 2010; Simley and Carswell, 2010). High TWI values represent low slope (flat) areas with a large upslope contributing area. Under dry conditions, areas with high TWI values tend to remain saturated 
Table 1. Results of principal components analysis on 16 landscape metrics defined for 33,799 individual catchments in the Northern Atlantic Coastal Plain.

[PC, principal component; loadings with absolute value greater than 0.7 are bold; loadings with absolute value less than 0.4 are omitted]

\begin{tabular}{|c|c|c|c|c|}
\hline \multirow{3}{*}{$\begin{array}{c}\text { Watershed } \\
\text { characteristic }\end{array}$} & PC1 & PC2 & PC3 & \multirow{3}{*}{$\begin{array}{c}\text { Communality } \\
\text { estimate }\end{array}$} \\
\hline & \multicolumn{3}{|c|}{ (percent of variance) } & \\
\hline & (43) & (19) & (16) & \\
\hline Percent hydric soils ${ }^{3}$ & 0.890 & & & 0.807 \\
\hline Mean soil hydric rating ${ }^{3,4}$ & 0.883 & & & 0.855 \\
\hline Mean topographic wetness index ${ }^{7}$ & 0.866 & & & 0.815 \\
\hline Mean soil percent organic matter ${ }^{3}$ & 0.410 & & & 0.248 \\
\hline Mean watershed slope, in percent ${ }^{1}$ & -0.857 & & & 0.806 \\
\hline Watershed relief, in meters ${ }^{1}$ & -0.817 & & & 0.733 \\
\hline Percent flat upland $d^{1,2,8}$ & 0.660 & -0.627 & & 0.907 \\
\hline Mean soil available water capacity ${ }^{3}$ & & & 0.734 & 0.710 \\
\hline Mean soil percent sand ${ }^{3}$ & & & -0.798 & 0.748 \\
\hline Mean soil saturated hydraulic conductivity ${ }^{3}$ & & & -0.702 & 0.673 \\
\hline
\end{tabular}

${ }^{1}$ Topographic metrics were computed from 30-meter digital elevation data (Gesch and others, 2009).

${ }^{2}$ Flat land is the percentage of the watershed with less than 1 percent slope.

${ }^{3}$ From the Soil Survey Geographic Database (SSURGO) (Natural Resources Conservation Service, 2007b).

${ }^{4}$ Soil hydric rating ranges from 1 (excessively drained) to 7 (very poorly drained).

${ }^{5}$ Soil hydrologic group ranges from 1 (soil class A) to 4 (soil class D).

${ }^{6}$ Soil drainage class ranges from 1 (excessively drained) to 7 (very poorly drained).

${ }^{7}$ TWI (Beven and Kirk, 1979; Wolock and McCabe, 1995) was computed from NHDPlus attributes (Horizon Systems, 2010; Simley and Carswell, 2010).

${ }^{8}$ Uplands (and lowlands) within each watershed are defined by areas above (or below) the midpoint elevation (the mean of the maximum and minimum elevation).

(Juracek, 2000). Also important to nitrate fate and transport in the surficial aquifer in the NACP is the orientation of local groundwater flowpaths relative to wetlands and nitrogen sources. Metrics quantifying the percentage of each catchment that is flat upland or flat lowland (table 1) were included to represent the likelihood of the depressional wetlands in each catchment occurring hydrologically upgradient or downgradient, respectively, of agriculture or other potential nitrogen sources. Depressional wetlands in watershed uplands are generally more likely be hydrologically upgradient of agriculture than those occurring in lowlands, and are therefore presumably less likely to intercept agricultural nitrogen. Depressional wetlands in the NACP often occur along drainage divides in forested areas that are upgradient of agriculture or other potential nitrogen sources and therefore have minimal impact on exported nitrogen loads. These wetlands can also be embedded within large expanses of wetland flats that have been drained for crop production and have minimal hydrologic gradients (DeSteven and Lowrance, 2011).

\section{Statistical Analysis and Interpretation}

Cluster analysis was used to group the 33,799 individual catchments in the study area into eight classes within which landscape metrics relevant to wetland occurrence and 
effectiveness at nitrogen mitigation are similar. Because the 16 landscape metrics are often correlated with one another and may contain redundant information, the cluster analysis was conducted on three principal components (PCs) summarizing the information in the 16 landscape metrics, rather than on the original metrics themselves.

PCA was used to identify and eliminate redundancy in the 16 wetland landscape metrics (McGarigal and others, 2000; SAS Institute, Inc., 2009). PCA generates uncorrelated PCs that are linear combinations of input variables, and simplifies subsequent analyses by removing correlation and redundancy among input variables (Helsel and Hirsch, 1992; McGarigal and others, 2000). Loadings (table 1) that illustrate how each $\mathrm{PC}$ is correlated with each input variable are computed and are useful in interpreting each PC (SAS Institute, Inc., 2009). For the wetland landscape model, PCA was run on standardized landscape metrics, and PC scores were computed to quantify how each of the 33,799 watershed catchments in the study area plot on each PC based on the values of the original input landscape metrics (SAS Institute, Inc., 2009).

Cluster analysis was used to classify the study-area catchments into clusters with relatively similar PC scores and therefore similar combinations of landscape characteristics (metrics) relevant to nitrogen mitigation by wetlands. Agglomerative clustering methods accumulate individual observations (data values) into continually larger clusters. In a hierarchical technique, the clusters are arranged into a structured hierarchy with relations that can be meaningful. Agglomerative hierarchical clustering techniques have been previously used for similar landscape analyses (for example, Lipscomb, 1998; Preston, 2000; Wolock and others, 2004). Clusters of catchments relevant to wetlands in the NACP were identified using Ward's minimum variance method, an agglomerative hierarchical clustering technique (SAS Institute, Inc., 2009) that joins clusters to minimize within-cluster variance (McGarigal and others, 2000). Although numerous guidelines are available, the number of clusters to retain and interpret is subjective, and was determined in this case through consideration of the clusters in light of their interpretability. Additional clusters may more accurately represent input data, but may also be more difficult to interpret and ultimately less useful.

Classes of watershed catchments were interpreted to predict the likely effects of depressional wetlands on nitrogen transport. Rank-transform analysis-of-variance and Tukey tests (Helsel and Hirsch, 1992) were used to compare values of landscape metrics and other geographic variables among clusters to support interpretation of the clusters and to evaluate the effectiveness of the cluster analysis. The likely effectiveness of depressional wetlands at mitigating nitrogen transport in each cluster was estimated on the basis of four factors: (1) the likelihood of the occurrence of such wetlands; (2) the relative position of likely wetlands along presumed hydrologic flowpaths; (3) selected soil properties; and (4) the likely position in the landscape of agricultural sources of nitrogen.

\section{Classification and Description of Wetland Landscapes in the Northern Atlantic Coastal Plain}

Statistical analyses (PCA and cluster analysis) were performed on the 16 landscape metrics and were used to classify each of the 33,799 original stream catchments into one of eight WLRs. Variable topography, soil conditions, and other landscape characteristics among the WLRs contribute to a similar variability in the likely effectiveness of depressional wetlands at mitigating nonpoint nitrogen transport in different parts of the NACP. The geographic model defined by the eight delineated WLRs can be used for watershed management and further research of regional nitrogen fate and transport.

\section{Statistical Analyses}

The 16 input landscape metrics are generally well correlated with one another and are therefore good candidates for PCA (table 1). The first three unrotated PCs explain at least 15 percent (individually) and 77 percent (collectively) of the variability in the 16 input landscape metrics (table 1), and were retained for cluster analysis. The first PC (PC1) explains nearly half ( 43 percent) of the variability in the input data and represents a measure of the likelihood of conditions conducive to the occurrence of depressional wetlands. Input landscape metrics with strong positive loading on PC1 include measures of overall catchment flatness (including overall flat land as well as flat land in uplands and lowlands) and indicators of poor drainage (including hydric soils and soil drainage class). PC1 is also moderately positively correlated with soil organic matter. Landscape metrics with strong negative loadings for PC1 include slope and relief (table 1). PC2 represents a distinction between catchments with flat lowlands (positive values) and those with flat uplands (negative values), which can be interpreted as an indicator of where wetlands in each catchment may occur relative to nitrogen sources (such as agriculture) along local topographic gradients and (presumably) hydrologic flowpaths from uplands towards lowlands. PC2 may also act as a surrogate for understanding stream incision that affects overall watershed drainage. PC3 is an indicator of soil texture. Catchments with negative values of PC3 contain relatively sandy, conductive soils; those with positive values include less well-drained soils with higher available water capacity (table 1).

Eight groups of catchments were selected from the cluster analysis based on the distribution of input landscape metrics reflected in the PCs (table 2). These eight groups (clusters) were selected on the basis of their interpretability and various metrics (McGarigal and others, 2000), and account for 68 percent of the variability in the input PC1, PC2, and PC3. The cluster results (table 2) represent a meaningful classification of the NACP with respect to the input landscape metrics; the distributions of input topographic (fig. 4) and soil (fig. 5) 
Table 2. Summary of depressional wetland landscape regions within the Northern Atlantic Coastal Plain.

[ $\mathrm{km}^{2}$, square kilometer; \%, percent; N/A, not applicable]

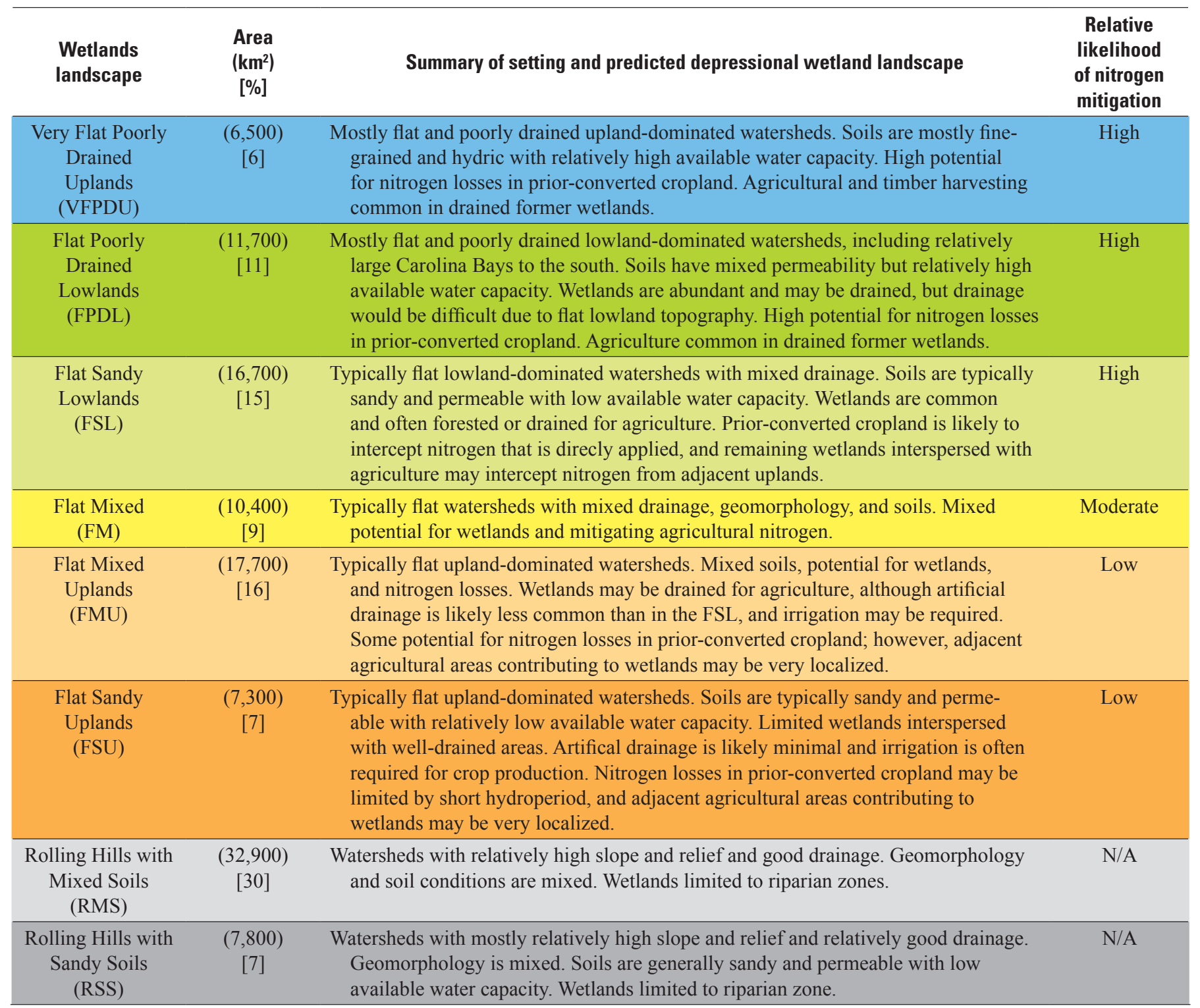

metrics generally vary significantly among the eight clusters. The distribution of different land covers also varies significantly among the eight clusters, and the occurrence of mapped wetlands are generally consistent with interpretations from the cluster-analysis based model (fig. 6).

\section{Wetland Landscape Regions}

Significant differences in topographic, soil, and other landscape conditions among the eight WLRs contribute to similar differences in the likely effects of depressional wetlands on nitrogen fate and transport.
The Very Flat Poorly Drained Uplands (VFPDU) cover $6,500 \mathrm{~km}^{2}$ of particularly flat near-coastal low-lying areas primarily in North Carolina and southern Virginia (fig. 7, table 2). Catchments in the VFPDU have significantly less relief and a greater percentage of flat land than in any other WLR. More than half of the catchments in the VFPDU include greater than 90 percent flat land; in no other WLR is the median percentage of flat land as high as 80 percent (fig. 4). Most of the flat land in VFPDU catchments is located within local uplands; VFPDU catchments are typically broad, flat plains with limited minor lowlands, likely including incised streams or artificial ditches (fig. 8). Much of the area of the VFPDU that 

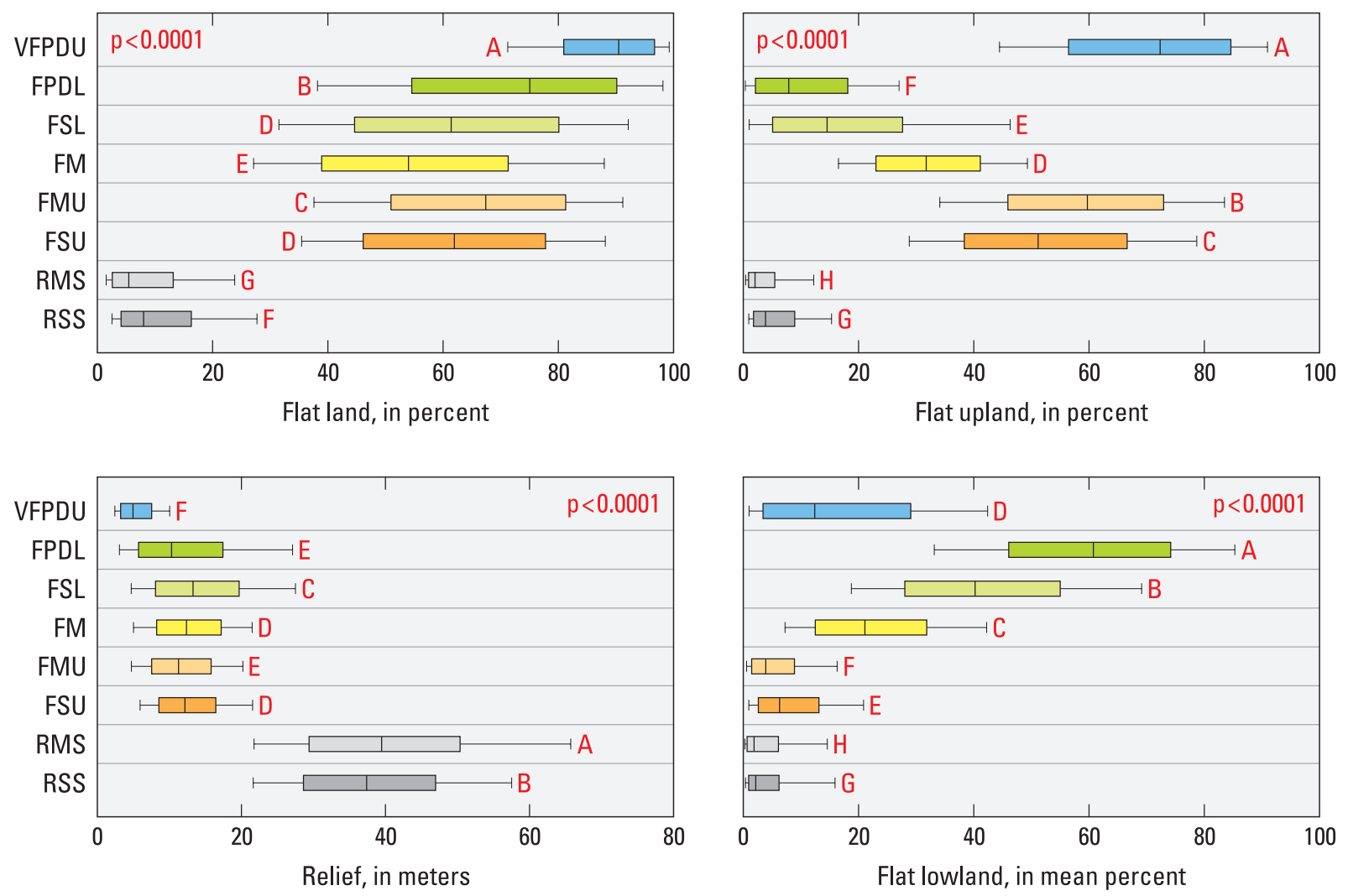

\section{EXPLANATION}

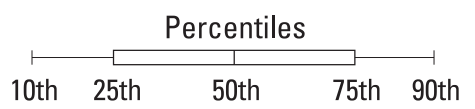

$p<0.0001$ The result of rank-transform analysis-of-variance test $(<$, less than).

A-H The result of rank-transform Tukey test. Wetland landscape regions with the same letter are not significantly different.

Elevation data from Gesch and others (2009).

Figure 4. Distribution of selected topographic metrics computed from 30-meter elevation data among wetland landscape regions (see table 2).

is currently cultivated was previously wetland flats. Soils in the VFPDU are significantly finer in texture with greater available water capacity (AWC) and more commonly hydric than in any other WLR (fig. 5). Soils in the VFPDU also contain significantly more organic matter than in most other WLRs. In spite of the soil conditions and extremely flat topography in the VFPDU, overall wetlands are less common than in other WLRs (fig. 6), likely due to artificial drainage (ditching) to support agriculture.

Natural or restored depressional wetlands in the VFPDU would likely have a high potential to mitigate nitrogen transport from nonpoint sources to local streams. The area is extremely flat and is underlain by organic soils with relatively high AWC and likely reducing geochemical conditions; water would move slowly through the low-gradient landscape providing ample opportunity for denitrification. The distinction between relative uplands and lowlands is probably less important in the VFPDU than in other WLRs with greater relief. Ditching in depressional wetlands and wetland flats in the VFPDU would lower the water table locally and induce greater flow from surrounding areas to the wetland, regardless of whether they are in natural relative "uplands" or "lowlands." Ditching of VFPDU wetlands may thus increase their effectiveness as nitrogen sinks, although ditching may 

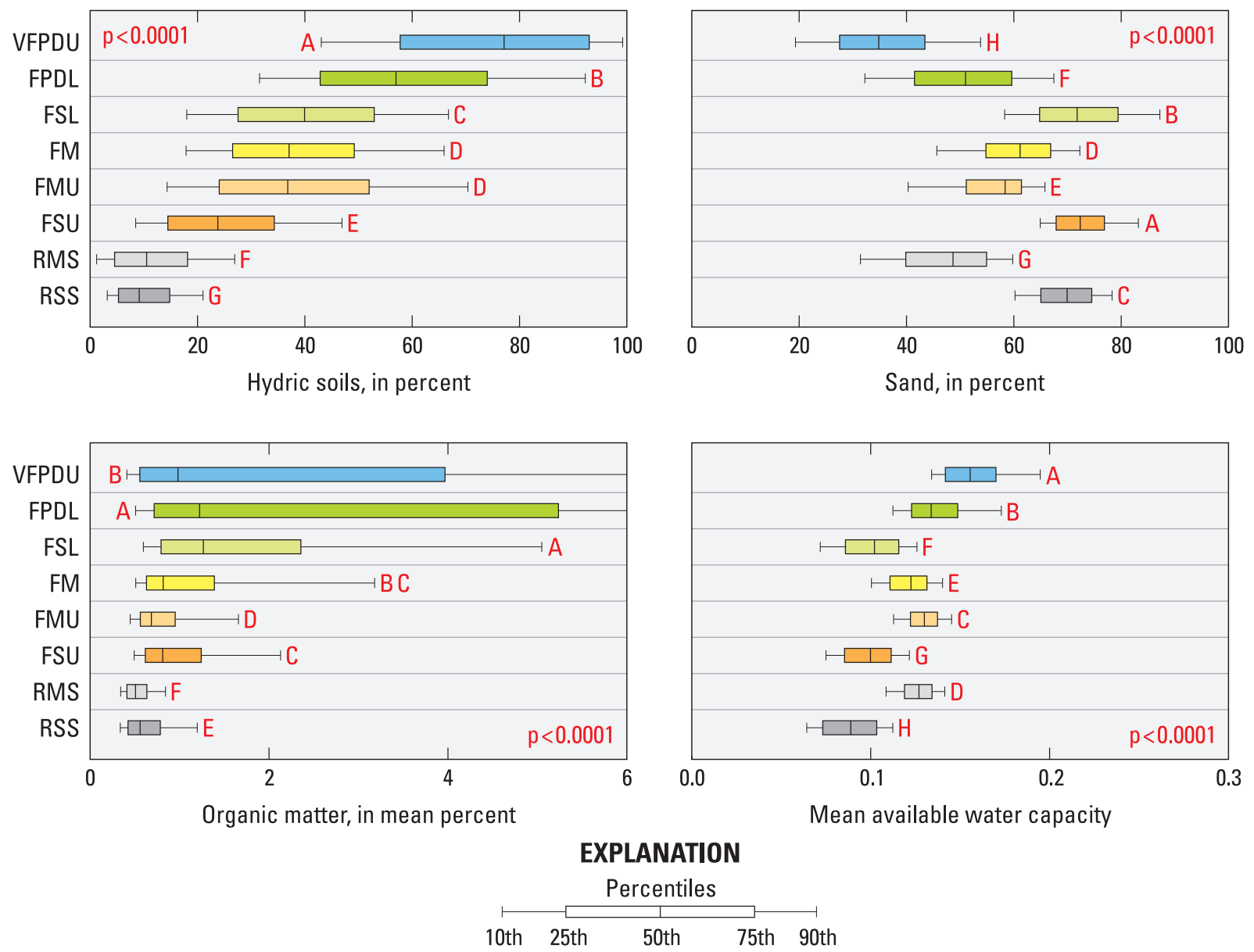

$p<0.0001$ The result of rank-transform analysis-of-variance test $(<$, less than).

$\mathrm{A}-\mathrm{H}$ The result of rank-transform Tukey test. Wetland landscape regions with the same letter are not significantly different.

Soil metrics from National Resources Conservation Service (2007b).

Figure 5. Distribution of selected soil metrics among wetland landscape regions (see table 2).

increase nitrogen transport from wetlands by reducing the length of groundwater flowpaths and therefore, the time available for denitrification to occur (Phillips and Donnelly, 2003). Successful drainage through artificial ditching may also oxidize upper soils and decrease the area of likely denitrification.

Catchments in the Flat Poorly Drained Lowlands (FPDL) cover 11,700 $\mathrm{km}^{2}$ of the NACP (fig. 7, table 2). FPDL catchments, many of which are likely former Carolina Bays, are interspersed among VFPDU catchments in much of North Carolina and southern Virginia, but also occur more widely throughout the Coastal Plain, particularly south of the Potomac River. As in the VFPDU, FPDL catchments are typically extremely flat with a median relief of less than $10 \mathrm{~m}$ (fig. 4) and likely formed in Carolina Bays and other landscape depressions (fig. 9). Unlike in the VFPDU, however, flat land in the FPDL is typically located within relative lowlands. Soils in the FPDL have greater mean AWC and are more commonly hydric than in any other WLRs except for the VFPDU, and are also relatively fine-grained and organic rich (fig. 5). Wetlands are more common in the FPDL than in any other WLR (fig. 6).

Among the eight WLRs, depressional wetlands in the FPDL may have the greatest potential to mitigate agricultural nitrogen. Soil and topographic conditions would promote slow movement of water and conditions favorable for denitrification in the FPDL, as in the VFPDU. Unlike in the VFPDU, however, the dominance of flat lowlands in the FPDL indicates that depressional wetlands, which are likely located in areas with drained wetland flats that are currently cultivated (fig. 9), may occur downgradient of nitrogen sources and be more likely to intercept nitrogen. The distinction between uplands 

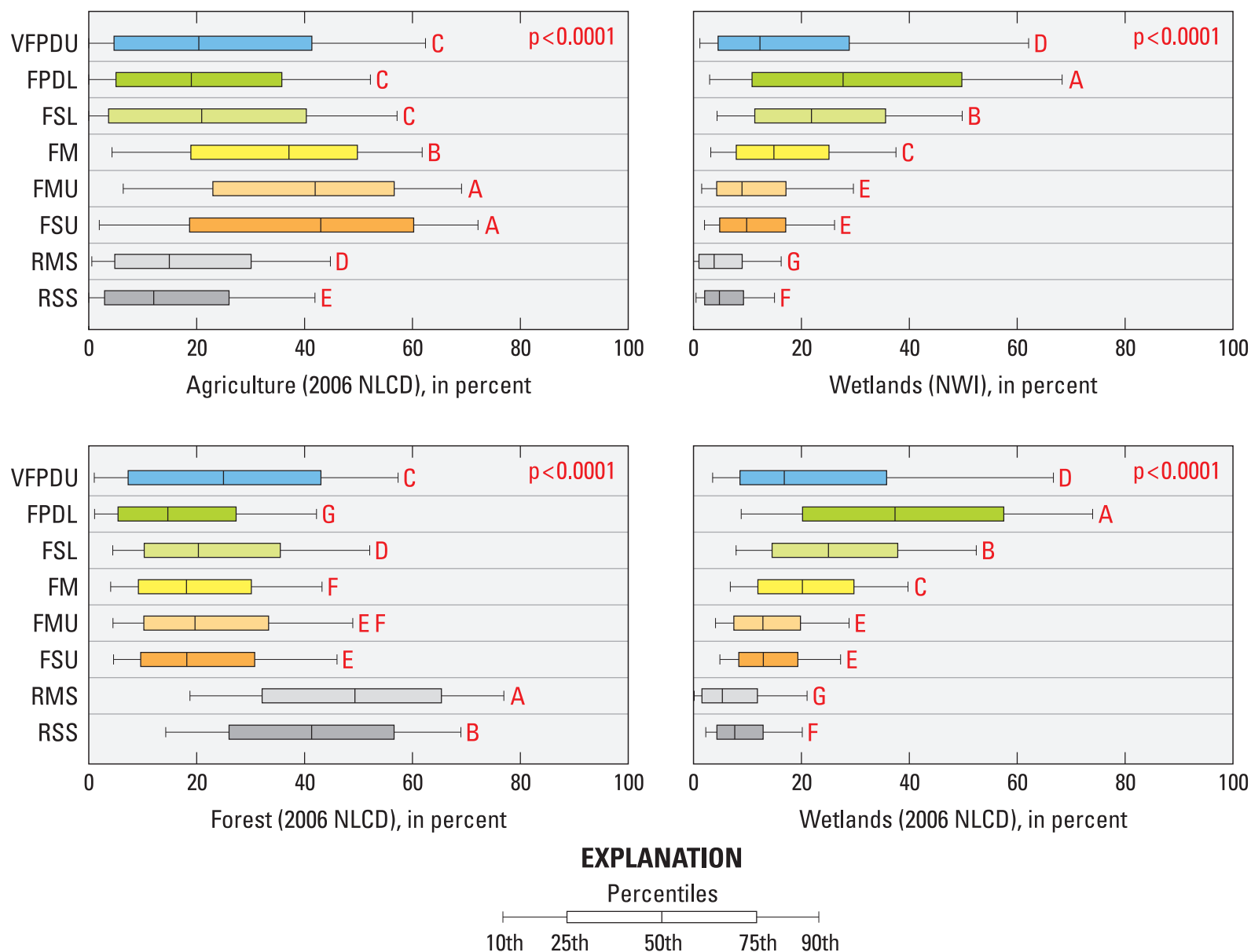

$p<0.0001$ The result of rank-transform analysis-of-variance test $(<$, less than).

$\mathrm{A}-\mathrm{H} \quad$ The result of rank-transform Tukey test. Wetland landscape regions with the same letter are not significantly different.

i. NWI: National Wetlands Inventory (U.S. Fish and Wildlife Service, 2011)

ii. 2006 NLCD: 2006 National Land Cover Data (Fry and others, 2011)

Figure 6. Distribution of selected land cover among wetland landscape regions (see table 2).

and lowlands may be relatively insignificant in the low-relief FPDL as in the VFPDU, however, and artificial drainage may draw groundwater toward wetlands regardless of apparent topographic position.

The Flat Sandy Lowlands (FSL) cover $16,700 \mathrm{~km}^{2}$ distributed over most of the Coastal Plain, particularly over broad areas of the Delmarva Peninsula and southern New Jersey, and also are common in southern North Carolina (fig. 7, table 2). FSL catchments are moderately flat, particularly in local watershed lowlands (fig. 4). Soils in FSL catchments are generally sandy with low mean AWC but relatively high organic matter content (fig. 5). The median coverage of hydric soils among FSL catchments is around 40 percent, and wetlands are more common in the FSL than in any other WLR except the FPDL (fig. 6).
Although wetlands, including isolated depressions (fig. 10a) and broader flat areas (fig. 10b), are relatively common in FSL catchments, the success of ditching to promote artificial drainage is likely facilitated by the moderate relief and permeable soils. Artificial drainage is common in agricultural areas developed on FSL areas; irrigation is generally not required (fig. 10). Because most wetlands likely occur in lowlands downgradient from agricultural nitrogen sources or are drained and cultivated, however, both natural and former (drained) wetlands likely have a high potential to mitigate nitrogen transport. By decreasing the residence time of water in organic-rich anoxic sediments that promote denitrification, however, ditching may alternatively increase nutrient transport from wetlands in the FSL, as in other landscape regions (Phillips and Donnelly, 2003). 


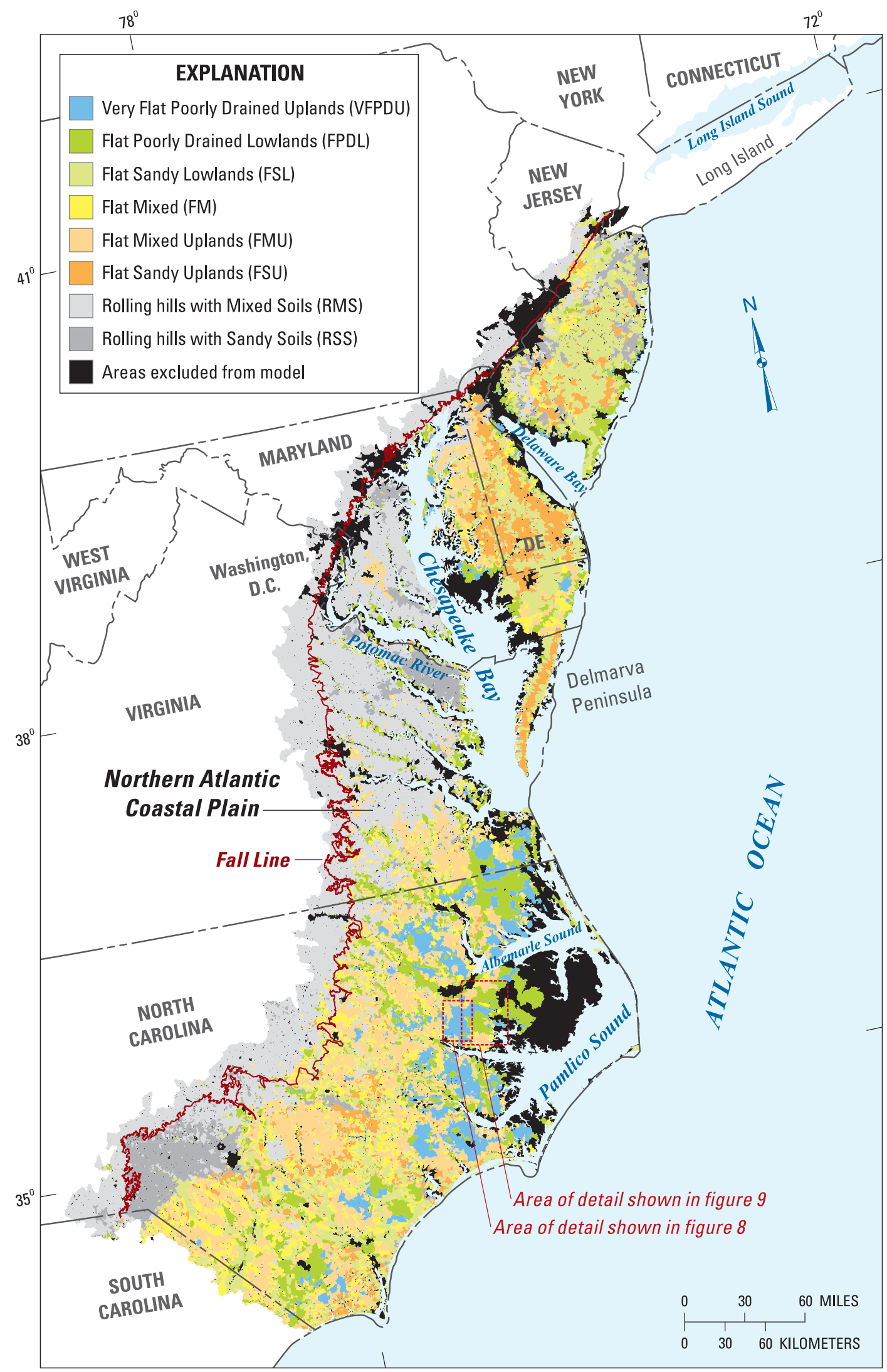

Base from U.S. Geological Survey, 1:2,000,000 DLG, Albers Equal-Area Conic Projection, NAD 1983

Figure 7. Wetland landscape regions within the Northern Atlantic Coastal Plain. 


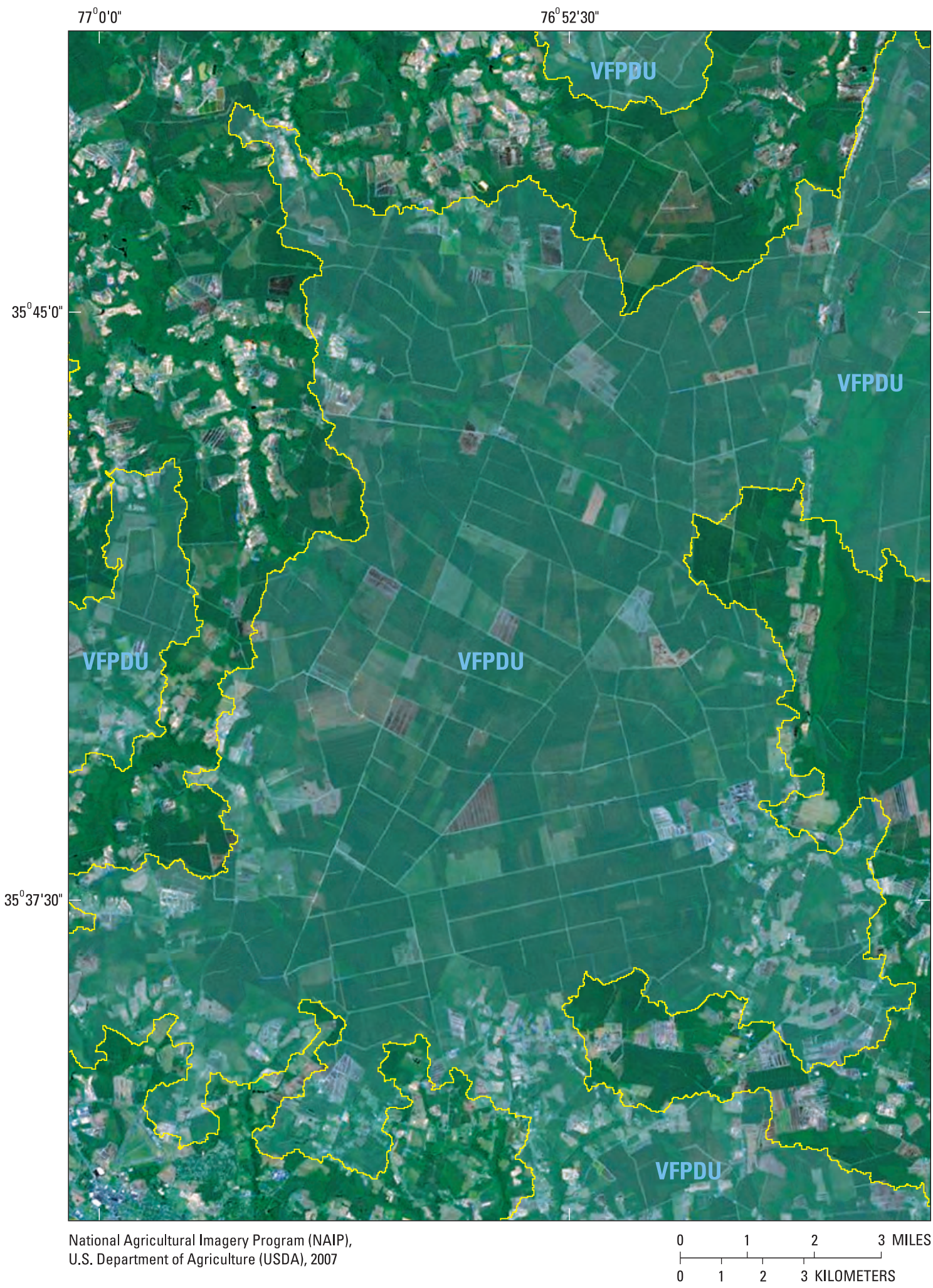

Figure 8. Parts of the Very Flat Poorly Drained Upland (VFPDU) in North Carolina. Much of the VFPDU is artificially drained for timber or row crop production. 


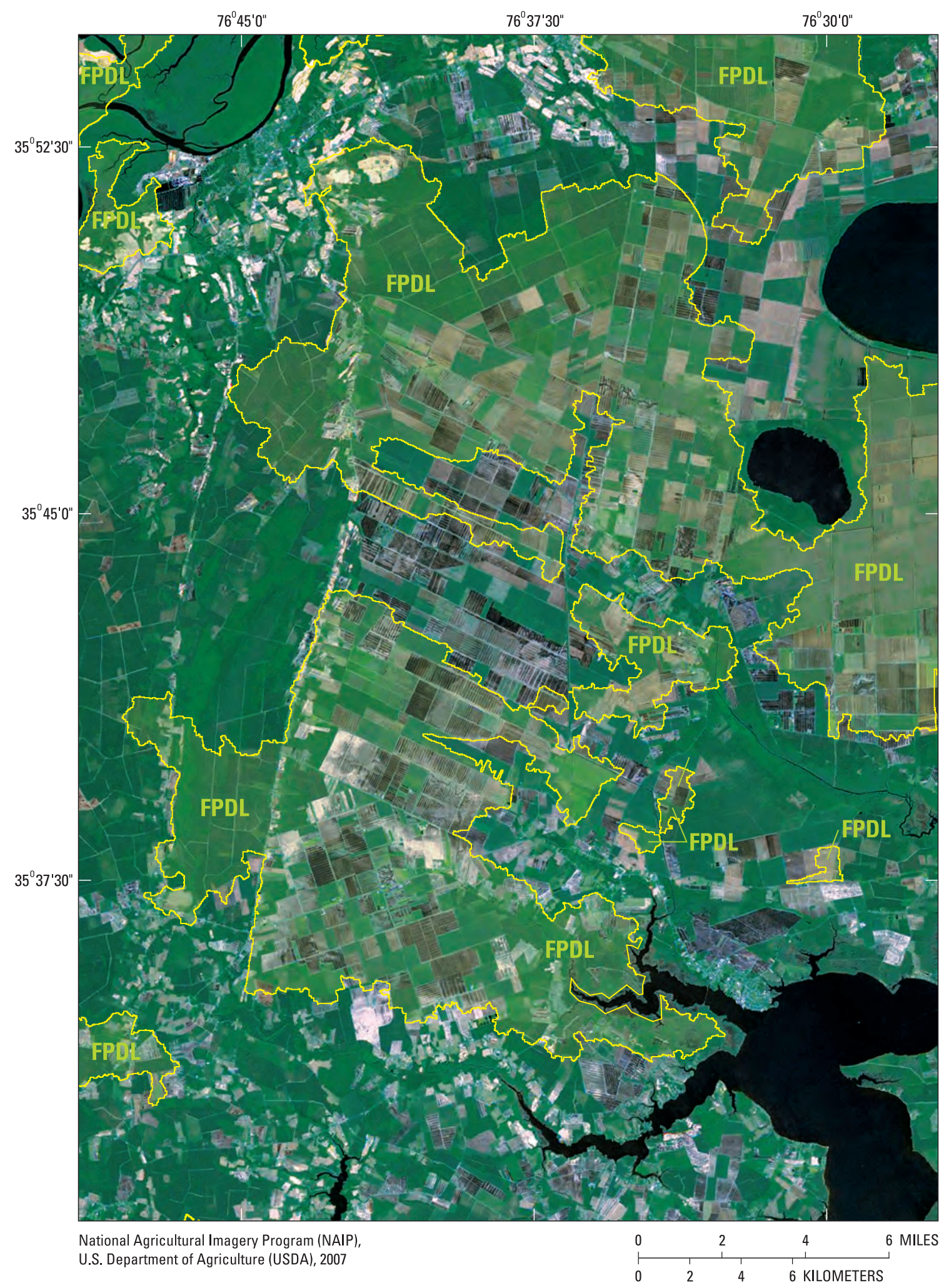

Figure 9. Flat Poorly Drained Lowlands (FPDL), as in this area of North Carolina, commonly form in large depressions such as Carolina Bays, and are often artificially drained for cultivation. 


\section{A}

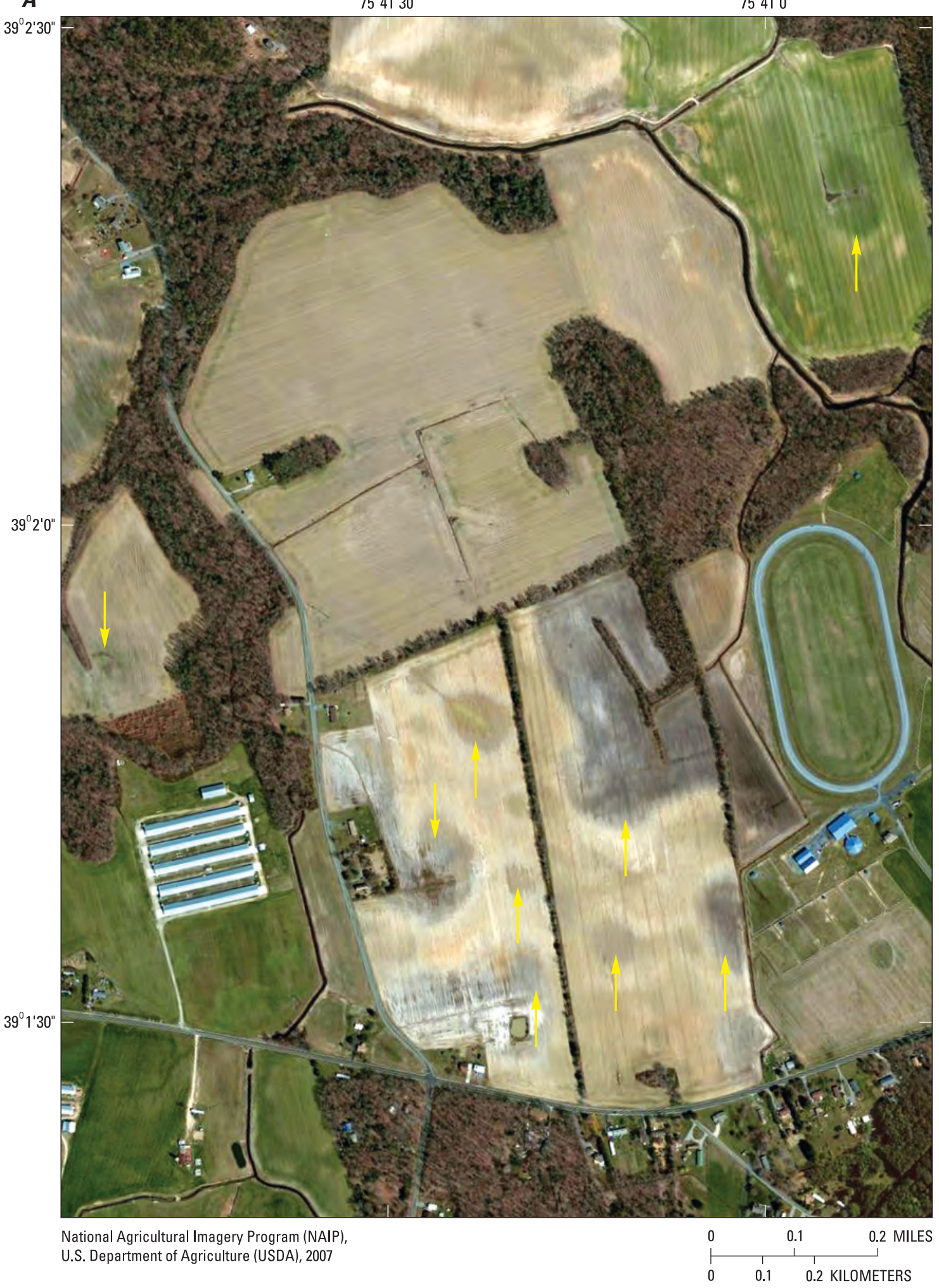

Figure 10. In the Flat Sandy Lowlands (FSL) in the northern part of the Delmarva Peninsula (A), wetlands often occur in isolated depressions, indicated by yellow arrows (such as Delmarva Bays), and minimal artificial drainage is required to support agriculture. Further south on the peninsula, however, $(B)$, natural drainage is extremely poor and extensive ditching is common. In neither area is irrigation often required. 


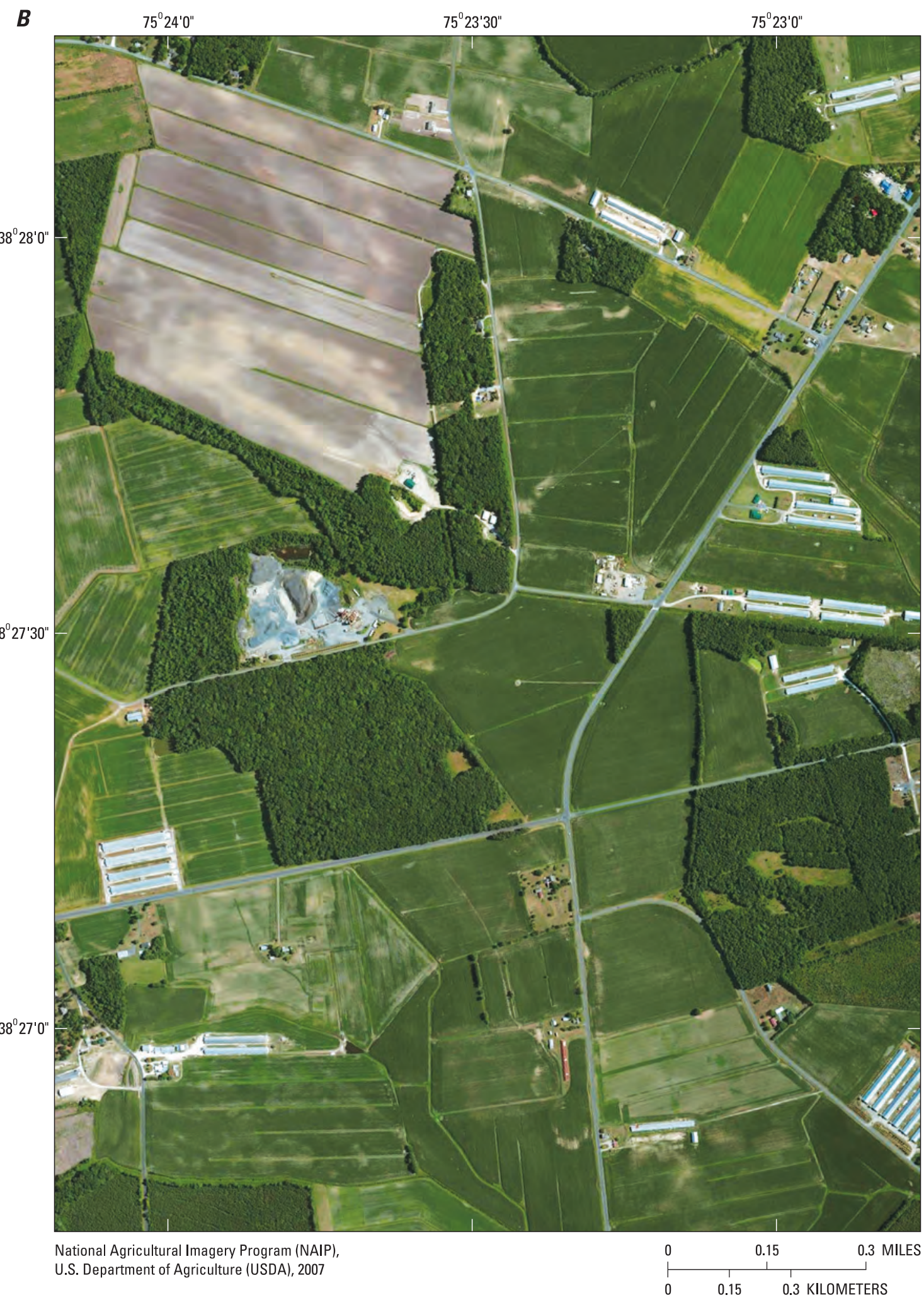

Figure 10. In the Flat Sandy Lowlands (FSL) in the northern part of the Delmarva Peninsula (A), wetlands often occur in isolated depressions, indicated by yellow arrows (such as Delmarva Bays), and minimal artificial drainage is required to support agriculture. Further south on the peninsula, however, $(B)$, natural drainage is extremely poor and extensive ditching is common. In neither area is irrigation often required.—Continued 
The Flat Mixed (FM) WLR covers $10,400 \mathrm{~km}^{2}$, dispersed widely throughout the Coastal Plain of North Carolina, southern Virginia, the Delmarva Peninsula, and southern New Jersey (fig. 7, table 2). FM catchments are generally flat areas that are relatively evenly distributed among local uplands and lowlands (fig. 4). Soil properties are moderate compared to the other seven WLRs, although the median percentage of hydric soils in FM catchments is nearly 40 percent (fig. 5). FM catchments generally contain more agriculture than VFPDU, FPDL, or FSL catchments, and less than 25 percent wetlands (fig. 6).

Generally mixed and moderate landscape and soil conditions contribute to a variable potential for nitrogen losses in depressional wetlands in the FM catchments. As in other WLRs, prior-converted wetlands will likely be effective at mitigating directly applied nitrogen, but the movement of nitrogen from adjacent areas will depend on local hydrologic gradients and flowpaths.

The Flat Mixed Uplands (FMU) and Flat Sandy Uplands (FSU) WLRs cover 25,000 $\mathrm{km}^{2}$ (collectively) over much of the Coastal Plain, particularly in North Carolina and the Delmarva Peninsula (fig. 7; table 2). The two WLRs represent very similar topographic settings, including low relief, incised streams, and a relatively high amount of flat land (greater than 60 percent), which is located mostly in local watershed uplands (fig. 4). The major difference between the FMU and FSU is in soil composition; soils in FSU catchments are generally sandier with lower mean AWC and are less commonly hydric, but include slightly greater organic content (fig. 5). As might be expected in broad, flat predominantly well-drained uplands, FSU and FMU catchments contain the greatest concentration of agriculture (more than 40 percent) of any WLR. Because of the efficient natural drainage, irrigation is often required for crop production (fig. 11). Wetlands cover 10 to 15 percent of each WLR and are mostly confined to riparian zones (fig. 6).

The likelihood of nitrogen mitigation in depressional wetlands is relatively low in catchments of the FMU and FSU WLRs. Wetlands are relatively rare in the flat uplands of these catchments, and those that do occur would be relatively easy to drain for cultivation, particularly in the permeable soils of the FSU. The relative upland location of large flat areas also suggests that wetlands that do occur in uplands may receive little drainage from agricultural areas.

The Rolling Hills with Mixed Soils (RMS) and Rolling Hills with Sandy Soils (RSS) WLRs are largely confined within the Coastal Plain to areas of Maryland and Virginia west of Chesapeake Bay (fig. 7). The RMS also covers most of the parts of the study area in the Piedmont Physiographic Province west of the Fall Line. RMS and RSS catchments have greater relief and less flat land, hydric soils, or soil organic matter than any other WLRs (fig. 4, fig. 5). Whereas RSS soils are relatively sandy with the lowest mean AWC of any WLR, RMS soils have a finer texture and greater mean AWC (fig. 5). Wetlands and agriculture are relatively uncommon in RMS and RSS catchments, as might be expected in light of the rolling topography; forest is the predominant land cover in both areas (fig. 6).

\section{Applications and Limitations}

The geographic model including the eight WLRs can be used for any application requiring an understanding of the spatial variability in the potential effectiveness of wetlands at mitigating nitrate transport from watershed uplands to streams. The WLRs represent areas of the Coastal Plain where nitrate losses to denitrification in depressional wetlands are more or less likely, and can therefore be used to target wetland restoration or conservation to areas where they may provide the greatest improvement in water quality. For example, restoration of wetlands along watershed divides may yield little improvement in the nitrogen loads in receiving streams, but such improvements may be substantial following restoration of lowland wetlands that have been artificially drained. The geographic model may also be useful for improving regional models of nitrogen fate and transport. Groundwater is a significant vector for nitrogen transport from the land surface to streams in the Coastal Plain (Bachman and Phillips, 1996; Ator and others, 2011; Ator and Denver, 2012), and denitrification is the only major sink for nitrate in groundwater. Regional models used to understand and manage nutrients often require spatially explicit delineations of factors affecting nitrogen fate and transport; such delineations of the effectiveness of depressional wetlands at nitrate mitigation have been previously lacking.

The effects of several limitations must be considered in using the geographic model of WLRs. Fundamental landscape units used in the model were derived from NHDPlus hydrography at the 1:100,000 scale. Although model predictions may be useful for broad regional areas, similarly reliable predictions for individual catchments or other areas smaller than a few square kilometers in size would likely require modeling at a finer resolution. The model results also are limited by the availability of input data representing landscape characteristics particularly relevant to nitrate fate and transport around wetlands. The thickness of the surficial aquifer, in particular, affects the formation of groundwater flowpaths and the likelihood that nitrate may pass beneath wetlands unaffected by reducing conditions (Gold and others, 2001; Puckett, 2004). The thickness of the surficial aquifer has not been mapped at sufficient resolution or consistency across the study area, and the lack of this information may limit the reliability of the WLRs. Similarly lacking is a consistent, comprehensive water-quality database against which to test the effectiveness of the WLRs at predicting nitrate concentrations in streams or groundwater. Calibration of the model with such data would greatly improve its usefulness for a variety of applications.

The geographic regionalization approach applied to the NACP has great potential to improve the understanding of nitrogen fate and transport around wetlands in other areas. Geographic analyses and statistical techniques have been used widely to delineate landscape areas with similar geographic features for a variety of applications (for example, Mosely, 1981; Lipscomb, 1998; Preston, 2000; Chiang and others, 2002; Caratti and others, 2004; Wolock and others, 2004; Rao 


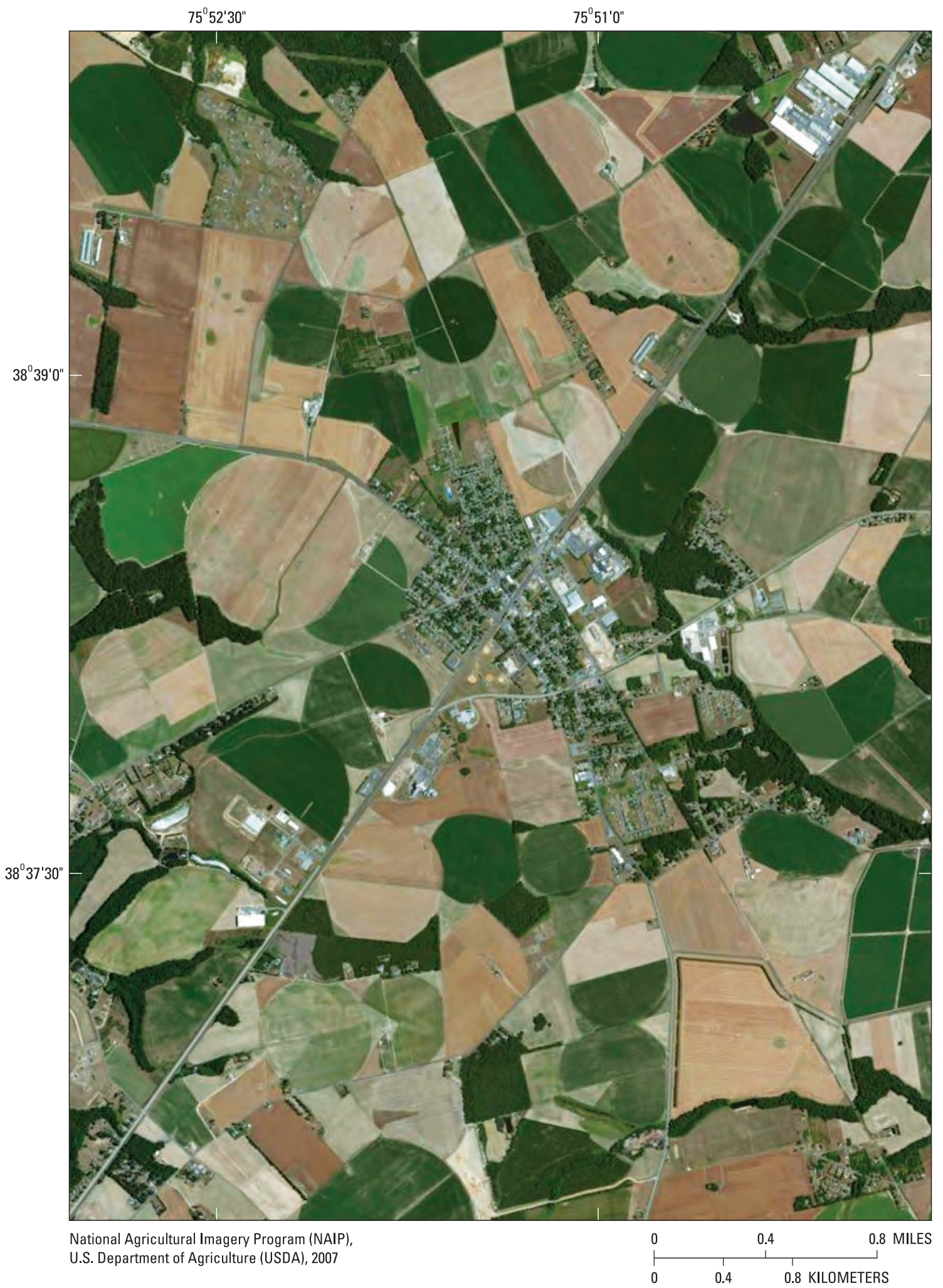

Figure 11. Circular fields in the Flat Sandy Uplands (FSU) near Hurlock, Maryland are indicative of center-pivot irrigation systems. Because FSU watersheds are generally well-drained, irrigation rather than artificial drainage is often used to support crop production. 
and Srinivas, 2006; Isik and Singh, 2008), and the landscape metrics relevant to wetland occurrence and nitrogen fate and transport in the Coastal Plain should be similar in other areas. The technique has the greatest potential for areas where such metrics are available and delineated for all the relevant variables. Conversely, a lack of certain types of information contributes significantly to uncertainty in the WLRs. For example, the formation of groundwater flowpaths as well as the fate and transport of nitrogen are heavily influenced by the thickness of the surficial aquifer, and a reliable spatial representation of this aquifer thickness is not currently available for the NACP. Suitable field data for use in calibrating the water-quality or other effects of geographic regions defined by cluster analyses would also be very useful in other areas where such techniques may be applied.

\section{Summary and Conclusions}

Abundant nonpoint sources of nitrogen to the land surface (such as agricultural fertilizer and manure applications) in much of the Northern Atlantic Coastal Plain (NACP) contribute to excessive nitrogen and resulting ecological stresses in area streams and receiving coastal estuaries such as Chesapeake Bay and Pamlico Sound. Depressional wetlands that are common in parts of the Coastal Plain can intercept and remove nitrogen applied in excess of plant uptake requirements from shallow groundwater and overland runoff during transport to surface waters; however, the effectiveness of different wetlands as sinks for nitrogen varies significantly with variations in hydrologic, geochemical, and soils conditions that are often poorly or inconsistently defined or mapped for large areas. The effectiveness of individual wetlands at removing nitrogen is therefore difficult to predict without extensive field investigations, and the importance of depressional wetlands to regional nitrogen budgets is often poorly quantified.

A regional geographic model was developed to delineate areas of the NACP within which depressional wetlands would likely be similarly effective at mitigating the transport of nitrogen from nonpoint sources to surface waters. Available hydrography at the 1:100,000 scale was used to define 33,799 individual watershed catchments in the Coastal Plain, and 16 landscape metrics particularly relevant to the occurrence of depressional wetlands and their effectiveness at mitigating nitrogen transport were defined for each catchment based primarily on available soil and topographic information. Principal components analysis (PCA) demonstrated that 78 percent of the variability in the 16 landscape metrics is attributable to three principal components (PCs) representing the probability of wetland occurrence, their likely position along hydrologic flowpaths, and soil composition. Cluster analysis was used to aggregate the 33,799 individual catchments into eight wetland landscape regions (WLRs) on the basis of these three PCs. Significant differences in topographic settings, soils, and land cover among the eight WLRs was used to evaluate the effectiveness of the cluster analysis and interpret the likely effects of wetlands at mitigating nitrogen transport.

The likely occurrence of depressional wetlands and their effectiveness at mitigating nitrogen transport to surface waters varies substantially over different areas of the Coastal Plain. The Very Flat Poorly Drained Uplands (VFPDU), Flat Poorly Drained Lowlands (FPDL), and Flat Sandy Lowlands (FSL), which include 32 percent of the Coastal Plain (collectively), are extremely flat and (or) low-lying and therefore very poorly drained. Natural and prior-converted depressional wetlands and wetland flats are common in these areas and have a relatively high potential to intercept nitrogen moving from the land surface to surface waters. Conversely, better natural drainage limits the occurrence of depressional wetlands in the Flat Mixed Uplands (FMU) and Flat Sandy Uplands (FSU), and the potential for nitrogen losses is relatively low in these WLRs, which collectively cover 23 percent of the Coastal Plain. Nine percent of the Coastal Plain is within the Flat Mixed (FM) WLR, which includes a wide range of drainage efficiencies, geomorphology, and soils, all of which contribute to its moderate likelihood of nitrogen mitigation. The Rolling Hills with Mixed Soils (RMS) and Rolling Hills with Sandy Soils (RSS) WLRs include 37 percent of the study area, with relatively high relief and slope. Wetlands in these areas are probably limited mainly to riparian zones.

The geographic model composed of the eight WLRs may be useful for numerous regional applications, but must be considered in light of inherent model assumptions and limitations. Delineation of landscapes most conducive to nitrogen mitigation by depressional wetlands should be very useful for targeting wetland conservation or restoration investments to protect water quality. The regional model may also be useful in water-quality models designed to estimate the regional effects of depressional wetlands on nitrogen transport from the Coastal Plain. Limitations in the model include a lack of regional water-quality data suitable for calibration and a lack of available input data characterizing certain landscape properties known to be important to nitrogen transport in groundwater, particularly the thickness of the surficial aquifer.

\section{References Cited}

Ator, S.W., 2008, Natural and human influences on water quality in a shallow regional unconsolidated aquifer, Northern Atlantic Coastal Plain: U.S. Geological Survey Scientific Investigations Report 2008-5190, 19 p. (also available online at $h t t p: / / p u b s . u s g s . g o v /$ sir/2008/5190/).

Ator, S.W., Brakebill, J.W., and Blomquist, J.D., 2011, Sources, fate, and transport of nitrogen and phosphorus in the Chesapeake Bay watershed: An empirical model: U.S. Geological Survey Scientific Investigations Report 20115167,27 p. (also available online at http://pubs.usgs.gov/ sir/2011/5167/). 
Ator, S.W., and Denver, J.M., 2012, Estimating contributions of nitrate and herbicides from groundwater to headwater streams, Northern Atlantic Coastal Plain, United States: Journal of the American Water Resources Association, v. 48, no. 6, p. 1,075-1,090, DOI: $10.1111 / \mathrm{j} .1752-1688.2012 .00672 . x$ (also available online at http://onlinelibrary.wiley.com/ doi/10.1111/j.1752-1688.2012.00672.x/abstract).

Ator, S.W., Denver, J.M., and Brayton, M.J., 2005, Hydrologic and geochemical controls on pesticide and nutrient transport to two streams on the Delmarva Peninsula: U.S. Geological Survey Scientific Investigations Report 20045051, 34 p. (also available online at http://pubs.usgs.gov/ sir/2004/5051/).

Ator, S.W., Denver, J.M., Krantz, D.E., Newell, W.L., and Martucci, S.K., 2005, A surficial hydrogeologic framework for the Mid-Atlantic Coastal Plain: U.S. Geological Survey Professional Paper 1680, 44 p. (also available online at http://pubs.usgs.gov/pp/2005/pp1680/).

Bachman, L.J., 1984, Nitrate in the Columbia aquifer, central Delmarva Peninsula, Maryland: U.S. Geological Survey Water-Resources Investigations Report 84-4322, 51 p.

Bachman, L.J., and Phillips, P.J., 1996, Hydrologic landscapes on the Delmarva Peninsula Part 2: Estimates of base-flow nitrogen load to Chesapeake Bay: Water Resources Bulletin, v. 32, no. 4, p. 779-791.

Beven, K.J., and Kirk, M.J., 1979, A physically-based, variable contributing area model of basin hydrology: Hydrologic Science Bulletin, v. 24, no. 1, p. 43-69.

Böhlke, J.K., and Denver, J.M., 1995, Combined use of groundwater dating, chemical, and isotopic analyses to resolve the history and fate of nitrate contamination in two agricultural watersheds, Atlantic Coastal Plain, Maryland: Water Resources Research, v. 31, no. 9, p. 2,319-2,339.

Böhlke, J.K., O’Connell, M.E., and Prestegaard, K.L., 2007, Ground water stratification and delivery of nitrate to an incised stream under varying flow conditions: Journal of Environmental Quality, v. 36, no. 3, p. 664-680, DOI: $10.2134 /$ jeq2006.0084.

Bolton, D.W., 1996, Network description and initial waterquality data from a statewide ground-water-quality network in Maryland: Maryland Geological Survey Report of Investigations No. 60, $167 \mathrm{p}$.

Brinson, M.M., and Eckles, S.D., 2011, U.S. Department of Agriculture conservation program and practice effects on wetland ecosystem services: a synthesis: Ecological Applications, v. 21, no. 3, Supplement, p. S116-S127, accessed October 19, 2012 at http://www.lsbarden.net/eLab/ Text/USDA.\&.Wetland.Services.2011.pdf.
Caratti, J.F., Nesser, J.A., and Maynard, C.L., 2004, Watershed classification using canonical correspondence analysis and clustering techniques: a cautionary note: Journal of the American Water Resources Association, v. 40, no. 5, p. $1,257-1,268$, DOI: $10.1111 /$ j.1752-1688.2004.tb01584.x.

Carpenter, S.R., Caraco, N.F., Correll, D.L., Howarth, R.W., Sharpley, A.N., and Smith, V.H., 1998, Nonpoint pollution of surface waters with phosphorus and nitrogen: Ecological Applications, v. 8, no. 3, p. 559-568.

Carter, Virginia, 1996, Wetland hydrology, water quality, and associated functions in Fretwell, J.D., Williams, J.S., and Redman, P.J., eds., National water summary on wetland resources: U.S. Geological Survey Water Supply Paper 2425 , p. $35-48$.

Chiang, S.M., Tsay, T.K., and Nix, S.J., 2002, Hydrologic regionalization of watersheds I-Methodology development: Journal of Water Resources Planning and Management, v. 128, no. 1, p. 3-11.

Cushing, E.M., Kantrowitz, I.H., and Taylor, K.R., 1973, Water resources of the Delmarva Peninsula: U.S. Geological Survey Professional Paper 822, $58 \mathrm{p}$.

Dahl, T.E., 1990, Wetlands-losses in the United States, 1790s to 1980s: Washington, D.C., U.S. Fish and Wildlife Service Report to Congress, $13 \mathrm{p}$.

David, M.B., McIsaac, G.F., Darmody, R.G., and Omonode, R.A., 2009, Long-term changes in mollisol organic carbon and nitrogen: Journal of Environmental Quality, v. 38, no. 1, p. 200-211.

Debrewer, L.M., Ator, S.W., and Denver, J.M., 2008, Temporal trends in nitrate and selected pesticides in Mid-Atlantic ground water: Journal of Environmental Quality, v. 37, Supplement, p. S296-S308, DOI: 10.2134/jeq2007.0664.

Denver, J.M., 1989, Effects of agricultural practices and septic-system effluent on the quality of water in the unconfined aquifer in parts of eastern Sussex County, Delaware: Delaware Geological Survey Report of Investigations No. $45,66 \mathrm{p}$.

Denver, J.M., Tesoriero, A.J., and Barbaro, J.R., 2010, Trends and transformations of nutrients and pesticides in a Coastal Plain aquifer system, United States: Journal of Environmental Quality, v. 39, no. 1, p. 154-167 (also available online at http://pubs.er.usgs.gov/ publication/70033949).

De Steven, D., and Lowrance R., 2011, Agricultural conservation practices and wetland ecosystem services in the wetland-rich Piedmont-Coastal Plain region: Ecological Applications, v. 21, no. 3, Supplement, p. S3-S17 (also available online at http://dx.doi.org/10.1890/09-0231.1). 
De Steven, D., Sharitz, R.R., Singer, J.H., and Barton, C.D., 2006, Testing a passive revegetation approach for restoring Coastal Plain depressional wetlands: Restoration Ecology, v 14, no. 3, p. 452-460, accessed October 19, 2012 at http://www.srs.fs.usda.gov/pubs/24460.

Domagalski, J.L., Ator, S.W., Coupe, R., McCarthy, K., Lampe, D., Sandstrom, M., and Baker, N., 2008, Comparative study of transport processes of nitrogen, phosphorus, and herbicides to streams in five agricultural basins, USA: Journal of Environmental Quality, v. 37, no. 3, p. $1,158-1,169$, DOI: $10.2134 /$ jeq2007.0408.

Dubrovsky, N.M., Burow, K.R., Clark, G.M., Gronberg, J.M., Hamilton, P.A., Hitt, K.J., Mueller, D.K., Munn, M.D., Nolan, B.T., Puckett, L.J., Rupert, M.G., Short, T.M., Spahr, N.E., Sprague, L.A., and Wilber, W.G., 2010, The quality of our Nation's waters - nutrients in the Nation's streams and groundwater, 1992-2004: U.S. Geological Survey Circular 1350, 174 p. (also available online at http://pubs.usgs.gov/ circ/1350/).

Dunkle, S.A., Plummer, L.N., Busenberg, Eurybiades, Phillips, P.J., Denver, J.M., Hamilton, P.A., Michel, R.L., and Coplen, T.B., 1993, Chlorofluorocarbons $\left(\mathrm{CCl}_{3} \mathrm{~F}\right.$ and $\mathrm{CCl}_{2} \mathrm{~F}_{2}$ ) as dating tools and hydrologic tracers in shallow groundwater of the Delmarva Peninsula, Atlantic Coastal Plain, United States: Water Resources Research, v. 29, no. 12 , p. 3,837-3,860, DOI: 10.1029/93WR02073.

Eckhardt, D.A.V., and Stackelberg, P.E., 1995, Relation of ground-water quality to land use on Long Island, New York: Ground Water, v. 33, no. 6, p. 1,019-1,033.

Fenneman, N.M., and Johnson, D.W., 1946, Physiographic divisions of the conterminous United States: U.S. Geological Survey Map, 1:7,000,000.

Fry, J., Xian, G., Jin, S., Dewitz, J., Homer, C., Yang, L., Barnes, C., Herold, N., and Wickham, J., 2011, Completion of the 2006 National Land Cover Database for the conterminous United States: Photogrammetric Engineering and Remote Sensing, v. 77, no. 9, p. 858-864.

Gesch, Dean, Evans, Gayla, Mauck, James, Hutchinson, John, and Carswell, W.J., Jr., 2009, The National MapElevation: U.S. Geological Survey Fact Sheet 2009-3053, 4 p. (also available online at $h t t p: / / p u b s . u s g s . g o v /$

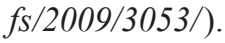

Gold, A.J., Groffman, P.M., Addy, Kelly, Kellogg, D.Q., Stolt, M., and Rosenblatt, A.E., 2001, Landscape attributes as controls on ground water nitrate removal capacity of riparian zones: Journal of the American Water Resources Association, v. 37, no. 6, p. 1,457-1,464, DOI: 10.1111/ j.1752-1688.2001.tb03652.x.

Helsel, D.R., and Hirsch, R.M., 1992, Statistical methods in water resources: Amsterdam, Elsevier Publishers, 522 p.
Hill, A.R., 1996, Nitrate removal in stream riparian zones: Journal of Environmental Quality, v. 25, no. 4, p. 743-755.

Horizon Systems, 2010, NHDPlus documentation, version 1, available online at ftp://ftp.horizon-systems.com/NHDPlus/ NHDPlusV1/documentation/NHDPLUSV1_UserGuide.pdf.

Howarth, R.W., Billen, G., Swaney, D., Townsend, A., Jaworski, N., Lajtha, K., Downing, J.A., Elmgren, R., Caraco, N., Jordan, T., Berendse, F., Freney, J., Kudeyarov, V., Murdoch, P., and Zhao-Liang, Z., 1996, Regional nitrogen budgets and riverine $\mathrm{N}$ and $\mathrm{P}$ fluxes for the drainages to the North Atlantic Ocean-Natural and human influences: Biogeochemistry, v. 35, p. 75-139.

Isik, S. and Singh, V.P., 2008, Hydrologic regionalization of watersheds in Turkey: Journal of Hydrologic Engineering, v. 13, no. 9, p. 824-834, DOI:10.1061/ (ASCE)1084-0699(2008)13:9(824).

Johnston, C.M., Dewald, T.G., Bondelid, T.R., Worstell, B.B., McKay, L.D., Rea, A., Moore, R.B., and Goodall, J.L., 2009, Evaluation of catchment delineation methods for the medium-resolution National Hydrography Dataset: U.S. Geological Survey Scientific Investigations Report 2009-5233, 89 p. (also available online at http://pubs.usgs. gov/sir/2009/5233/).

Juracek, K.E., 2000, Estimation of potential runoff-contributing areas in Kansas using topographic, soil, and land-use information: U.S. Geological Survey Water-Resources Investigations Report 00-4177, 55 p., accessed October 19, 2012 at http://ks.water.usgs.gov/pubs/reports/wrir.00-4177. html.

Kauffman, L.J., Baehr, A.L., Ayers, M.A., and Stackelberg, P.E., 2001, Effects of land use and travel time on the distribution of nitrate in the Kirkwood-Cohansey Aquifer System in southern New Jersey: U.S. Geological Survey Water-Resources Investigations Report 01-4117, 49 p. (also available online at http://pubs.usgs.gov/wri/wri01-4117/).

Kennedy, C.D., Genereux, D.P., Corbett, D.R., and Mitasova, H., 2009, Relationships among groundwater age, denitrification, and the coupled groundwater and nitrogen fluxes through a streambed: Water Resources Research, v. 45, no. 9, 18 p., DOI:10.1029/2008WR07400.

LaMotte, A.E., 2008a, National Land Cover Database 2001 (NLCD01) Tile 2, northeast United States: NLCD01_2: U.S. Geological Survey Data Series DS-383B, available online only at http://water.usgs.gov/GIS/metadata/usgswrd/ XML/nlcd01_2.xml.

LaMotte, A.E., 2008b, National Land Cover Database 2001 (NLCD01) Tile 4, southeast United States: NLCD01_4: U.S. Geological Survey Data Series DS-383D, available online only at $h t t p: / / w a t e r . u s g s . g o v / G I S / m e t a d a t a / u s g s w r d /$ $X M L / n l c d 01$ 4.xml. 
Lang, M., and McCarty, G., 2009, LiDAR intensity for improved detection of inundation below the forest canopy: Wetlands, v. 29, no. 4, p. 1,166-1,178.

Leahy, P.P., and Martin, M., 1993, Geohydrology and simulation of ground-water flow in the Northern Atlantic Coastal Plain aquifer system: U.S. Geological Survey Professional Paper 1404-K, 81 p. (also available online at http://pubs. usgs.gov/pp/1404k/report.pdf).

Leibowitz, S.G., and Nadeau, T.-L, 2003, Isolated wetlands: State-of-the-science and future directions: Wetlands, v. 23, no. 3, p. 662-683.

Lipscomb, S.W., 1998, Hydrologic classification and estimation of basin and hydrologic characteristics of subbasins in central Idaho: U.S. Geological Survey Professional Paper $1604,49 \mathrm{p}$.

McFarland, E.R., 1995, Ground-water flow, geochemistry, and effects of agricultural practices on nitrogen transport at study sites in the Piedmont and Coastal Plain Physiographic Provinces, Patuxent River Basin, Maryland: U.S. Geological Survey Open-File Report 94-507, 78 p.

McGarigal, K., Cushman, S., and Stafford, S., 2000, Multivariate statistics for wildlife and ecology research: New York, Springer Science and Business Media, 283 p.

Mehnert, E., Hwang, H.H., Johnson, T.M., Sanford, R.A., Beaumont, W.C., and Holm, T.R., 2007, Denitrification in the shallow ground water of a tile-drained, agricultural watershed: Journal of Environmental Quality, v. 36, no. 1, p. $80-90$.

Mosely, M.P., 1981, Delimitation of New Zealand hydrologic regions: Journal of Hydrology, v. 49, p. 173-192.

Natural Resources Conservation Service, 2007a, Watershed boundary dataset for the United States, vector digital data, accessed July 26, 2010 at http://datagateway.nrcs.usda.gov.

Natural Resources Conservation Service, 2007b, Soil Survey Geographic Database (SSURGO) data packaging and use, accessed October 30, 2011 at $h t t p: / / s o i l d a t a m a r t . n r c s . u s d a$. gov/SSURGOMetadata.aspx.

Palmer, M.A., and Filoso, Solange, 2009, Restoration of ecosystem services for environmental markets: Science, v. 325, p. $575-576$.

Phillips, S.W., and Donnelly, C.A., 2003, Upper Pocomoke watershed, in Lindsey, B.D., Phillips, S.W., Donnelly, C.A., Speiran, G.K., Plummer, L.N., Böhlke, J.K., Focazio, M.J., Burton, W.C., and Busenberg, Eurybiades, Residence times and nitrate transport in ground water discharging to streams in the Chesapeake Bay watershed: U.S. Geological Survey Water-Resources Investigations Report 03-4035, 201 p.
Prasad, M.B.K., Sapiano, M.R.P., Anderson, C.R., Long, Wen, and Murtugudde, R., 2010, Long-term variability of nutrients and chlorophyll in the Chesapeake Bay: A retrospective analysis, 1985-2008: Estuaries and Coasts v. 33, no. 5, p. $1,128-1,143$, DOI: $10.1007 / \mathrm{s} 12237-010-9325-\mathrm{y}$.

Preston, S.D., 2000, Statistical identification of hydrochemical response units for hydrologic monitoring and modeling in Maryland: U.S. Geological Survey Water-Resources Investigations Report 00-4232, 7 p.

Puckett, L.J., 2004, Hydrogeologic controls on the transport and fate of nitrate in ground water beneath riparian buffer zones: Results from thirteen studies across the United States: Water Science and Technology, v. 49, no. 3, p. 47-53, accessed October 19, 2012 at http://water.usgs. gov/nawqa/nutrients/pubs/wst_v49_no3/wst_v49_no3.pdf.

Puckett, L.J., Zamora, Celia, Essaid, Hedeff, Wilson, J.T., Johnson, H.M., Brayton, M.J., and Vogel, J.R., 2008, Transport and fate of nitrate at the ground-water/surfacewater interface: Journal of Environmental Quality, v. 37, no. 3, p. 1,034-1,050.

Rao, A.R., and Srinivas, V.V., 2006, Regionalization of watersheds by fuzzy cluster analysis: Journal of Hydrology, v. 318, nos. 1-4, p. 57-79, DOI.10.1016/j. jhydrol.2005.06.004.

Richardson, C.J., 1983, Pocosins-Vanishing wastelands or valuable wetlands?: Bioscience, v. 33, no. 10, p. 626-633.

SAS Institute, Inc., 2009, SAS/STAT 9.2 users's guide, (2d ed.): Cary, North Carolina: SAS Institute, Inc., 7,869 p.

Simley, J.D., and Carswell, W.J., Jr., 2010, The National Map-Hydrography: U.S. Geological Survey Fact Sheet 2009-3054, 4 p. (also available online at http://pubs.usgs. gov/fs/2009/3054/).

Sinnott, A., and Cushing, E.M., 1978, Summary appraisals of the Nation's ground-water resources-Mid-Atlantic region: U.S. Geological Survey Professional Paper 813-I, 32 p.

Speiran, G.K., 1996, Geohydrology and geochemistry near coastal ground-water-discharge areas of the Eastern Shore, Virginia: U.S. Geological Survey Water Supply Paper 2479,73 p. (also available online at http://pubs.er.usgs.gov/ publication/wsp2479).

Spruill, T.B., Eimers, J.L., and Morey, A.E., 1997, Nitratenitrogen concentrations in shallow ground water of the Coastal Plain of the Albemarle-Pamlico drainage study unit, North Carolina and Virginia: U.S. Geological Survey Fact Sheet 241-96, 4 p., accessed October 20, 2012 at http:// nc.water.usgs.gov/reports/fs24196/. 
Spruill, T.B., Tesoriero, A.J., Mew, H.E., Jr., Farrell, K.M., Harden, S.L., Colosimo, A.B., and Kraemer, S.R., 2005, Geochemistry and characterization of nitrogen transport at a confined animal feeding operation in a Coastal Plain agricultural watershed, and implications for nutrient loading in the Neuse River Basin, North Carolina, 1999-2002: U.S. Geological Survey Scientific Investigations Report 2004-5283, 66 p. (also available online at http://pubs.usgs. gov/sir/2004/5283/).

Szabo, Zoltan, Rice, D.E., Plummer, L.N., Busenberg, Eurybiades, Drenkard, Stefan, and Schlosser, Peter, 1996, Age-dating of shallow groundwater with chlorofluorocarbons, tritium/helium 3, and flow path analysis, southern New Jersey Coastal Plain: Water Resources Research, v. 32, no. 4, p. 1,023-1,038.

Tesoriero, A.J., Liebscher, Hugh, and Cox, S.E., 2000, Mechanism and rate of denitrification in an agricultural watershed: Electron and mass balance along groundwater flow paths: Water Resources Research, v. 36, no. 6, p. 1,545-1,559, DOI:10.1029/2000WR900035.

Tiner, R.W., 1996, Wetland definitions and classification in the United States, in Fretwell, J.D., Williams, J.S., and Redman, P.J., eds., National water wummary on wetland resources: U.S. Geological Survey Water Supply Paper 2425, p. $27-34$.

U.S. Environmental Protection Agency, 2007, National Estuary Program coastal condition report: Washington, D.C., U.S Environmental Protection Agency Report EPA842/B-06/001, 445 p.

U.S. Environmental Protection Agency, 2008, Chesapeake Bay health and restoration assessment: Washington, D.C., U.S. Environmental Protection Agency Report EPA903-R-08-002, 33 p.

U.S. Environmental Protection Agency, 2011, Final Chesapeake Bay TMDL, accessed May 11, 2011 at http:// www.epa.gov/reg3wapd/tmdl/ChesapeakeBay/tmdlexec. html.

U.S. Fish and Wildlife Service, 2011, Classification of wetlands and deepwater habitats of the United States: Washington, D.C., U.S. Fish and Wildlife Service Report FWS/OBS-79/31, 131 p.

U.S. Geological Survey and U.S. Department of Agriculture, Natural Resources Conservation Service, 2012, Federal Standards and Procedures for the National Watershed Boundary Dataset (WBD) (3d ed.): U.S. Geological Survey Techniques and Methods 11-A3, 63 p. (also available online at http://pubs.usgs.gov/tm/tm11a3/).
Vitousek, P.M., Aber, J.D., Howarth, R.W., Likens, G.E., Matson, P.A., Schindler, D.W., Schlesinger, W.H., and Tilman, D.G., 1997, Human alteration of the global nitrogen cycle: Sources and consequences: Ecological Applications, v. 7 , no. 3, p. 737-750.

Whigham, D.F., and Jordan, T.E., 2003, Isolated wetlands and water quality: Wetlands, v. 23, no. 3, p. 541-549.

Winner, M.D., Jr., and Coble, R.W., 1996, Hydrogeologic framework of the North Carolina Coastal Plain: U.S. Geological Survey Professional Paper 1404-I, 106 p. (also available online at http://pubs.usgs.gov/pp/1404i/report. pdf).

Winter, T.C., 2001, The concept of hydrologic landscapes: Journal of the American Water Resources Association, v. 37 , no. 2, p. 335-349.

Wolock, D.M, and McCabe, G.J., 1995, Comparison of single and multiple flow-direction algorithms for computing topographic parameters in TOPMODEL: Water Resources Research, v. 31, p. 1,315-1,324.

Wolock, D.M., Winter, T.C., and McMahon, G., 2004, Delineation and evaluation of hydrologic-landscape regions in the United States using geographic information system tools and multivariate statistical analyses: Environmental Management, v. 34, Supplement 1, p. S71-S88, DOI:10.1007/s00267-003-5077-9.

\section{Appendix}

Wetland landscape regions (WLRs) in the Northern Atlantic Coastal Plain are available online in a commadelimited ASCII file at http://pubs.usgs.gov/sir/2012/5266/ nacp_wlrs.csv. Variables in the file are described in the header (denoted by lines starting with "\#”) and also include the principal component scores that were derived from principal components analysis on the 16 original landscape metrics and were used in cluster analysis to create the WLRs. The file includes predictions for local catchments contributing to 33,799 stream reaches in the Coastal Plain as defined by the National Hydrography Dataset Plus (NHDPlus) medium resolution (1:100,000-scale) geospatial dataset (Horizon Systems, 2010).

\section{Reference Cited}

Horizon Systems, 2010, NHDPlus documentation, version 1, available online at ftp://ftp.horizon-systems.com/NHDPlus/ NHDPlusV1/documentation/NHDPLUSV1_UserGuide.pdf. 

Prepared by USGS West Trenton Publishing Service Center. Edited by Valerie M. Gaine.

Graphics and layout by Timothy W. Auer.

For additional information, contact:

Director, MD-DE-DC Water Science Center

U.S. Geological Survey

5522 Research Park Drive

Baltimore, MD 21228

or visit our Web site at:

http://md.water.usgs.gov 
Printed on recycled paper

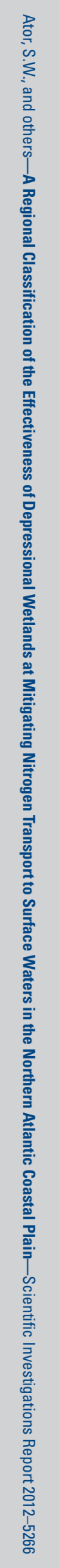

